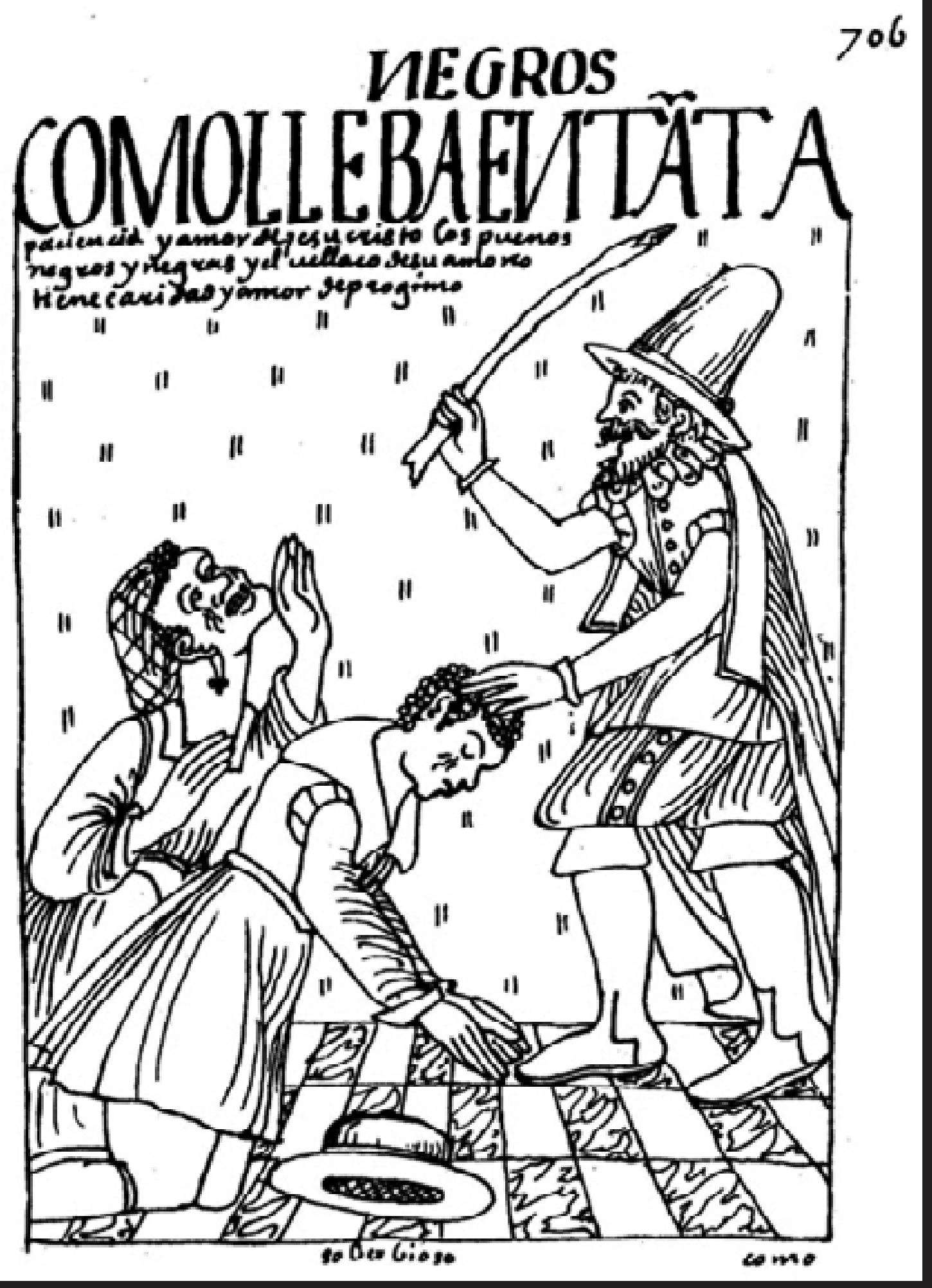




\section{Los vicios y virtudes en las imágenes de la Nueva corónica y buen gobierno de Felipe Guaman Poma de Ayala: la violencia entre la justicia y la soberbia The vices and virtues in the images of the Nueva corónica y buen gobierno by Felipe Guaman Poma de Ayala: the violence between justice and arrogance Os vícios e virtudes nas imagens da Nueva corónica y buen gobierno de Felipe Guaman Poma de Ayala: a violência entre justiça e arrogância}

Diana Roselly Pérez Gerardo

Universidad Autónoma Metropolitana-

Iztapalapa (México)

dianaroselly@hotmail.com
Este artículo se desprende de la investigación sobre historiografía de tradición indígena en el Perú que efectué entre agosto de 2012 y junio de 2017, para mi tesis de Doctorado en Historia en la UNAM.

\begin{abstract}
Resumen
Desde un análisis historiográfico se examina la representación gráfica de los vicios y las virtudes en la Nueva corónica y buen gobierno de $\mathrm{Fe}-$ lipe Guaman Poma de Ayala. A partir de los cánones vigentes en la época, que concebían a la historia como herramienta didáctica indispensable para la educación y moralización de la sociedad y de la influencia que la política tridentina ejerció sobre el autor, se contrastan las representaciones de los vicios y las virtudes, tanto de los indios como de los españoles, a lo largo de la obra. Así mismo, se observa la relación que el autor establece entre la noción de justicia y el temor al castigo; de modo que proponemos distinguir aquella violencia asociada al orden y al buen gobierno incaico de las escenas que denuncian el pecado de la soberbia al retratar los abusos perpetrados por españoles y por algunos indios en la colonia.
\end{abstract}

Palabras clave

Guaman Poma; historiografía; imágenes, vicios y virtudes; justicia y soberbia

\begin{abstract}
We examine, from a historiographic analysis, the graphic representation of vices and virtues in the Nueva corónica y buen gobierno by Felipe Guaman Poma de Ayala. We contrast the representations of vices and virtues, both of the Indians and of the Spaniards, throughout the work, based on the canons in force at the time, which conceived history as an indispensable didactic tool for the education and moralization of society, and under the influence that Tridentine politics exerted on the author. Likewise, we observe the relationship that the author establishes between the notion of justice and the fear of punishment; thus, we propose to distinguish the violence associated with the order and the good Inca government from the scenes that denounce the sin of arrogance thought the portrayal of the abuses perpetrated by Spaniards and by some Indians in the colony.
\end{abstract}

\section{Keywords}

Guaman Poma; historiography; images; vices and virtues; justice and arrogance

\section{Resumo}

Desde uma análise historiográfica examina-se a representação gráfica dos vícios e as virtudes na Nueva corónica y buen gobierno de Felipe Guaman Poma de Ayala. A partir dos cânones em vigor na época, que concebiam a historia como ferramenta didática indispensável para a educação e moralização da sociedade e da influência que a política tridentina exerceu sobre o autor, são contrastadas as representações dos vícios e virtudes, tanto dos índios quanto dos espanhóis, ao largo da obra. Mesmo assim, observa-se a relação que o autor estabelece entre a noção de justiça e o medo da punição; é assim que propomos distinguir aquela violência associada à ordem e bom governo incaico das cenas que denunciam o pecado da arrogância ao retratar os abusos perpetrados pelos espanhóis e alguns índios na colônia.

\section{Palavras-chave}

Guaman Poma; historiografia; imagens, vícios e virtudes; justiça e arrogância

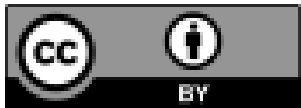

/ Mem.soc / Bogotá (Colombia) / ISSN 0122-5197 (impreso) - ISSN 2248-6992 (en línea) / 21 (43): 104-130 /julio-diciembre de 2017 / $\mathbf{D 5}$ 


\section{Introducción}

En el último siglo, las imágenes que ilustran la Nueva corónica y buen gobierno escrita por Felipe Guaman Poma de Ayala a inicios del siglo XVII, han inundado el imaginario gráfico sobre la historia andina. Las casi cuatrocientas láminas con dibujos que aparecen en la obra ${ }^{1}$ se han convertido en el repositorio al que se acude para ilustrar aspectos concretos de la historia andina, tales como: ceremonias, oficios, cargos administrativos y personajes tanto prehispánicos como coloniales. De este modo, la iconografía de Guaman Poma se puede encontrar en edificios públicos (por ejemplo, en la enorme pared del Korikancha en Cusco, tapizada con decenas de estas imágenes o los lienzos de gran formato exhibidos en bibliotecas públicas y universidades de la misma ciudad), así como en cualquier afiche o portada de libro cuyo asunto, evento o tema esté relacionado con los incas y la historia andina. Incluso se han llegado a editar obras de otros autores, como los Comentarios reales de los incas de Garcilaso de la Vega, con ilustraciones de la obra de Guaman Poma de Ayala, ${ }^{2}$ generando así la idea de que sus informaciones son intercambiables o al menos que coinciden en sus juicios y valoraciones sobre la historia andina. De este modo, la reproducción constante de los dibujos de Guaman, en los más diversos formatos y con las más disímiles intenciones, ha logrado desprenderlas del contexto específico en el que fueron generadas y del propósito específico que el autor les concedió al incorporarlas a su crónica, una misiva que estaba dirigida al Rey Felipe III.
Dada la complejidad de la circunstancia colonial desde la que escribe el autor, y de los motivos que lo movieron a emprender una obra acompañada de imágenes, considero indispensable la comprensión cabal de la misma como una totalidad. Es decir, propongo que, bajo un paradigma historiográfico, se pregunte por el «marco de referencias históricas en que la obra alcanza su mayor significatividad». ${ }^{3} \mathrm{La}$ Nueva corónica y buen gobierno de Felipe Guaman Poma de Ayala, en tanto obra historiográfica, puede y debe ser considerada como un hecho histórico en sí misma, sujeta a los vaivenes del devenir histórico y a su autor como un ser humano que recurrió a la historia como respuesta a las exigencias concretas que le apremiaban para enfrentar el futuro, o, lo que es lo mismo, para "poner el pasado al servicio de la vida». ${ }^{4}$ Bajo este enfoque, la escisión de la obra entre imágenes y texto o entre tradición andina y tradición española resulta ajena al autor, a su contexto y a su intencionalidad y, por ende, artificial.

\section{Imagen y texto en la Nueva corónica y buen gobierno}

Por lo anterior, este trabajo parte del supuesto de que existe una relación intrínseca entre el texto y las imágenes, que es mucho más evidente en el manuscrito original, ${ }^{5}$ en tanto que en él es posible ver el orden en el que el autor dispuso la colocación de dichas imágenes. Los dibujos de la Nueva corónica ocupan fojas completas $(21,7 \times 14,7 \mathrm{~cm})$, no tienen color, cuentan con un marco que las delimita y con un título en la parte superior, y, en algunas ocasiones, tienen otras anotaciones distribuidas

3 Edmundo O'Gorman, Cuatro historiadores de Indias, Siglo XVI (México: Alianza Editorial Mexicana - CONACULTA, 1972), 19.

4 Edmundo O'Gorman define el pragmatismo futurista como «la manera de adecuar el pasado a las exigencias del presente, es decir una operación que consiste en poner al pasado (concebido bajo la noción de hecho histórico) al servicio de la vida», Edmundo O’Gorman, «Historia y vida», en La teoría de la historia en México (1940-1973), ed. Álvaro Matute (México: SEP, 1974), 147.

5 El manuscrito original, GKS 2232 4:: Guaman Poma, Nueva corónica y buen gobierno (1615), se encuentra en la Biblioteca Real de Dinamarca y fue descubierto en 1908 por Richard Pietschmann. Es posible consultarlo en línea en: http://www.kb.dk/permalink/2006 
dentro del recuadro del dibujo o en la base. ${ }^{6}$ Todas las láminas con imágenes se encuentran intercaladas en la obra, y en tanto el manuscrito está escrito a doble cara, suelen tener texto en el reverso. En general, cada imagen está en estrecha vinculación con el texto que le sigue; es decir, antecede a la narración y representa lo que el autor describe en ella; complementan y refuerzan de manera gráfica la idea que el autor pretende plasmar en su relato. ${ }^{7}$ Por lo inteligible de las escenas representadas, la sencillez en el trazo y dado que se trata de las escasas imágenes con las que se cuenta entre las crónicas coloniales peruanas, ${ }^{8}$ estos dibujos se han reproducido constantemente sin que se incluya necesariamente la información del texto que las acompañaba originalmente.

La separación de las imágenes del texto se ha dado no solo de manera casual, sino que ha sido objeto de disquisiciones acerca del contenido y sentido de estas. Algunos autores incluso han llegado a afirmar de manera contundente que las imágenes de la crónica de Guaman Poma están en franca oposición al texto: «En efecto, al considerar el texto escrito de la obra, es más probable que el autor sea interpretado como alguien que expresó apreciaciones negativas del mundo andino, en tanto que al efectuar interpretaciones del texto iconográfico, destacan aspectos positivos respecto

6 Este formato también se encuentra en los llamados «libros modelo», medio por el cual se diseminaba, durante la Edad Media, el arte. Dos ejemplos de ellos son: el Rollo Vercelli y el Credo de Joinville, ambos del siglo XIII. El evidente parecido de estos libros con el estilo de imagen de Guaman Poma ha sido trabajado por Augusta E. Holland, Nueva corónica: Tradiciones artísticas europeas en el virreinato del Perú (Cuzco: Centro de Estudios Regionales Andinos Bartolomé de las Casas, 2008), 36-40.

7 En esto concuerdan Carlos González, Hugo Rosati y Francisco Sánchez, quienes concluyen que «Las láminas constituyen una verdadera nueva crónica que se complementa con la escrita, formando así una gran unidad». «Sinopsis del estudio de la iconografía de la Nueva corónica y buen gobierno escrita por Felipe Guaman Poma de Ayala», Historia 34 (2001): 88.

8 La crónica escrita por Fray Martín de Murúa, la Historia general del Perú, origen y descendencia de los Incas, también tuvo ilustraciones de acuarelas que se semejan mucho a las imágenes de Guaman Poma; la vinculación entre ambos autores ha sido trabajada especialmente por Juan M. Ossio. Por otra parte, la crónica de Juan Santa Cruz Pachacuti incluye algunos cuantos esquemas que no pueden ser considerados como ilustraciones propiamente, además de que son muy pocos. Juan M. Ossio, En busca del orden perdido. La idea de la Historia en Felipe Guaman Poma de Ayala (Lima: Pontificia Universidad Católica del Perú, 2008), 51-65. de los Andes y con relación a las culturas que se desarrollaron en tal entorno». ${ }^{9}$

Pese al calculado vínculo que Guaman Poma estableció entre las láminas y el texto, Lozada y otros investigadores han considerado a las imágenes como depositarias de un discurso distinto e incluso opuesto al del texto escrito. Entre otras aproximaciones similares, encontramos la de Rolena Adorno y la de Mercedes López Baralt. La primera de ellas, analiza el «texto pictórico» de la obra de Guaman «como un sistema de comunicación completo y válido en sí», mediante el cual el autor «manifiesta una crítica virulenta hacia los colonizadores españoles a través de un texto secreto dentro de otro texto». ${ }^{10}$ Baralt, por su parte, propone que en los dibujos de Guaman Poma es posible encontrar plasmada la lógica andina, y afirma que en la obra de Guaman Poma «la escritura llega a depender del dibujo en tanto texto fecundo en sentidos implícitos que estructuran un mensaje ajeno a la lógica occidental». ${ }^{11}$ De ambas interpretaciones me aparto por dos razones: la primera es que si bien es evidente e innegable la influencia indígena en la representación simbólica del universo de Guaman, también son evidentes sus influencias gráficas occidentales, de modo que el intento de distinguirlas y separarlas es ajeno a la intención del mismo autor, quien se esforzó por unirlas de manera coherente, sin oponerlas como distantes e irreconciliables. La segunda razón es que desde la presente perspectiva de abordaje, que es la historiográfica historicista vitalista, procuro privilegiar el drama ontológico del personaje que lucha por justificar su lugar como funcionario legítimo dentro del orden colonial al servicio del rey sobre el interés de reivindicar exclusivamente

9 Blithz Lozada Pereira, Cosmovisión, historia y política en los Andes (La Paz: CIMA, 2006).

10 Rolena Adorno, «Paradigmas perdidos: Guaman Poma examina la sociedad española colonial», Revista Chungará, n. ${ }^{\circ} 13$ (1984): 67. En un trabajo posterior, Adorno vuelve sobre la idea de una «tipología cultural» que destaca, a pesar de la asimilación, los valores de la cultura andina. «Sobre el lenguaje pictórico y la tipología cultural en una crónica andina», Revista Chungará, n. ${ }^{\circ}$ 18 (1987): 101.

11 Mercedes López Baralt, Icono y conquista. Guaman Poma de Ayala (Madrid: Hiperión, 1988), 409. 
su crítica a ese orden, al que también pretendía pertenecer y contribuir. Sin embargo, coincido con Adorno en que «la totalidad de los modelos composicionales son tan solo pedazos rotos de un esquema prototipo", ${ }^{12} \mathrm{de}$ modo que difícilmente una propuesta de análisis podrá dar cuenta de un esquema común a los cuatro centenares de imágenes de la obra, motivo por el cual este trabajo se centra en el tópico de vicios y virtudes.

Por otra parte, la socióloga boliviana Silvia Rivera Cusicanqui se ha aproximado a estas imágenes bajo el supuesto de que, en el marco del colonialismo, «las palabras se convirtieron en un registro ficcional, plagado de eufemismos que velan la realidad en lugar de designarla», ${ }^{13}$ por lo que ella concede a las imágenes una preeminencia en cuanto a la perspectiva andina del autor, dado que considera que estas permiten «descubrir sentidos no censurados por la lengua oficial». ${ }^{14} \mathrm{Si}$ bien critica la aproximación estructuralista de Adorno, coincide con ella en que en las imágenes de Guaman constituyen un sistema visual que ofrece narrativas de comprensión crítica de la realidad en la medida en que sostiene que el orden colonial invirtió el mundo. A ello, sumo que si bien la oposición entre orden y desorden es clara en las imágenes, esta se encuentra detallada en el texto, pues las múltiples determinaciones que cruzan al autor, así como sus vínculos con la administración colonial, hacen que dicha oposición sea muy compleja, llena de matices, sin esencializaciones raciales, al tiempo que abren la posibilidad de alcanzar un buen gobierno colonial. ${ }^{15}$

Las aproximaciones enunciadas comparten un par de supuestos; el primero de ellos es que las imágenes de la Nueva corónica son independientes

12 Adorno, «Paradigmas perdidos», 89.

13 Silvia Rivera Cusicanqui, «Sociología de la imagen. Una visión desde la historia colonial andina», en Ch'hixinakax utxiwa. Una reflexión sobre prácticas y discursos descolonizadores (La Paz: Tinta Limón Retazos, 2010), 19.

14 Rivera Cusicanqui, «Sociología de la imagen», 21.

15 A esta particular idea se opone Rivera al decir que en los dibujos de Guaman Poma hay elementos conceptuales y teóricos que «apuntan a la imposibilidad de una dominación legítima y de un buen gobierno en un contexto colonial"». Rivera Cusicanqui, «Sociología de la imagen», 26. del resto de la obra. Y si bien estas presentan una riqueza suficiente para ser analizadas de forma autónoma al texto, no debe perderse de vista que el autor las concibió como un apoyo visual que hiciera más llevadera la lectura de su texto. La obra es, en este sentido, un todo en el que las imágenes se encuentran estrechamente vinculadas al discurso escrito. Al menos así declara el autor su intención:

Pasé trauajo para sacar con el deseo de presentar a vuestra Magestad este dicho libro yntitulado Primer nueua corónica de las Yndias del Pirú y prouechoso a los dichos fieles cristianos, escrito y debojado de mi mano y engenio para que la uaridad de ellas y de las pinturas y la enbinción y dibuxo a que vuestra Magestad es enclinado haga fázil aquel peso y molestia de una letura falta de enbinción y de aquel ornamento y polido ystilo que en los grandes engeniosos se hallan. ${ }^{16}$

De acuerdo con el autor, las imágenes, de su propia mano, están ahí para facilitar la lectura a su Majestad el Rey Felipe, para hacer más digerible, más atractiva y más útil la lectura de su texto.

El segundo supuesto que subyace es la noción dicotómica entre aculturación y resistencia, pues al conceder al discurso gráfico la capacidad de mostrar las estructuras andinas que no se ven en el texto, se alude a una concepción sustantivista de la cultura en la que toda modificación de esquemas es percibida como pérdida de la pureza original en el camino hacia una aculturación total. Ante ello es preciso reconocer la circunstancia específica del autor, de sus necesidades vitales y de la respuesta que fraguó ante el dilema que enfrentaba. ${ }^{17}$

Guaman Poma de Ayala nació y creció después de la conquista del Perú, «le tocó vivir el proceso de afianzamiento del sistema colonial español y [...], muy probablemente, en la década de 1580 o quizá un poco antes, comenzó a

16 Felipe Guaman Poma de Ayala, El primer nueva corónica y buen gobierno (edición crítica revisada para la versión digital de John V. Murra y Rolena Adorno, traducciones y análisis textual del quechua por Jorge L. Urioste) (Copenhague: Biblioteca Real de Dinamarca, 2001), f. 10 [10]. Conservo la ortografía original de esta edición.

17 Para un análisis de la obra de Guaman Poma en función de su experiencia vital y mundo conocido, véase: Diana Roselly Pérez Gerardo, «Historiografía de tradición indígena en el Perú» (Tesis de Doctorado en Historia, UNAM, 2017). 
perfilar su obra histórica» ${ }^{18}$ Es decir, su educación, sus influencias, sus fuentes, su experiencia en sí, se formaron en la transición entre un orden destrozado y otro que apenas se configuraba. Guaman encarnaba el conflicto y buscaba para sí una forma de estar en ese mundo en construcción. Fue la necesidad vital lo que lo movió a buscar en su pasado una manera de identificarse, y la descripción de su presente le permitió encontrar la posibilidad de ubicarse a sí mismo en el mundo colonial y de esbozar un lugar desde el cual pudiera contribuir para el mejor funcionamiento de ese nuevo orden.

El autor de la Nueva corónica y buen gobierno ha pasado a la historia como uno de los grandes críticos del orden colonial, de los abusos, de la injusticia, y su obra así lo demuestra. Sin embargo, no pugnaba por la expulsión de los españoles, ni por la reconstitución del imperio inca, como tampoco por el abandono de la religión católica; Guaman asumía la continuidad de ese sistema, se incluía en él y buscaba el mejor lugar para estar dentro. Para legitimarse trenzó sus dos raigambres, aparentemente irreconciliables, y configuró una sola: la suya. Por ello considero que resulta forzado hacer una distinción entre los elementos andinos y los elementos europeos que priman en una o en otra parte de la obra, pues el intento de fundir tradiciones no está exento de conflicto. Felipe Guaman Poma de Ayala criticaba los abusos de los funcionarios, pero pedía prebendas para sí mismo; asumía con creces todas las tensiones para integrase al nuevo orden; despreciaba a los incas casi tanto como a los españoles; repudiaba la mezcla de razas, como él mismo las llamaba; aborrecía a los mestizos y reconocía a los buenos cristianos españoles.

En todo caso, el autor utiliza los elementos que tiene a su alcance para elaborar un discurso coherente y consistente en el que no separa ni distingue de manera nítida las tradiciones española e indígena; se esfuerza por delinear los matices y se empeña en demostrar

18 Juan M. Ossio, En busca del orden perdido. La idea de la Historia en Felipe Guaman Poma de Ayala (Lima: Pontificia Universidad Católica del Perú, 2008), 74. las diferencias definitorias que existían entre los pueblos preincaicos y los incas. Tampoco habla en nombre de todos los indígenas del Perú, sino que defiende la posición de los indios principales; su defensa es una defensa de grupo y no la de todos los indios andinos; del mismo modo, bosqueja a españoles buenos cristianos y a otros que no temen a Dios.

Privilegiando la circunstancia del autor y en función del canon historiográfico vigente en la época que considera a la historia como maestra de vida, se llevará a cabo el análisis de un grupo de imágenes articuladas por las escenas de violencia, para presentar la relación que el autor establece entre la noción de justicia y el temor al castigo (físico o divino). Para presentar la complicada relación entre las reiteradas imágenes de la crueldad con el cuadro de vicios y virtudes, característico del modelo retórico de las crónicas coloniales, proponemos distinguir aquella violencia asociada a la justicia, al orden y al buen gobierno inca de aquellas escenas que pretenden denunciar el pecado de la soberbia por medio de imágenes que retratan los abusos de los españoles y también los de algunos indios.

Al distinguir aquellos casos en los cuales la violencia explícita de las imágenes apunta a proyectar los vicios del mal gobierno colonial de aquellos en los que se trata de ilustrar las virtudes asociadas a la fuerza y los eficaces castigos incas, la hipótesis a trabajar consiste en que la asociación dicotómica de indio virtuoso y español vicioso no alcanza a dar cuenta del enorme abanico de matices introducido por el autor. Así como retrata el buen gobierno inca, los acusa de idólatras, denuncia a indios bajos $\mathrm{y}$ viciosos y reconoce a aquellos que son buenos cristianos; culpa a algunos españoles por enseñar el pecado a los indios, pero enaltece a quienes son compasivos, caritativos y humildes; compara incluso a los buenos y pacientes esclavos con los españoles soberbiosos. Pero la gran cantidad de matices solo es perceptible en el constante y obligado cotejo de las imágenes con el texto al que acompañan. 


\section{El modelo retórico y el cuadro de vicios y virtudes}

La historia, como un género integrante de la poética, mantenía, para el siglo XVI, la función principal de ser «maestra de vida». Es decir, la narración del pasado se enmarcaba en las verdades morales que debían servir como ejemplo y material didáctico para enseñar a los lectores a vivir una vida ejemplar. Esta noción deriva en principio de la concepción aristotélica de la retórica, entendida como una disciplina útil para perfeccionar la habilidad de argumentar en aras de persuadir acerca de cosas probables. La retórica como método didáctico se divulgó a través de Cicerón, y en la Edad Media se le agregó «una perspectiva cristiana que considera que todo libro debe de ser edificante, es decir, debe contribuir a afianzar la fe», ${ }^{19} \mathrm{y}$ por ello presenta modelos de vida cristiana deseables e imitables. De este modo,

Durante el siglo XVI, la escritura de la historia estaba regida por la retórica, como técnica persuasiva, lo que le exigía a sus cronistas el esfuerzo por integrar la tradición cristiana con las verdades morales, por lo que más que mostrar «hechos verdaderos», pretendían presentar un cuadro de vicios y virtudes. ${ }^{20}$

Para ello, el modelo retórico acudía a tres estrategias que concedían mayor fuerza expresiva a la narración: la primera es la descripción. En tanto se trata de un género demostrativo, ${ }^{21}$ la descripción es la herramienta natural para la argumentación histórica, pues a partir de ella se ilustra o se evidencia la imagen que se

19 Lydia Fossa, Narrativas problemáticas. Los inkas bajo la pluma española (Lima: Pontificia Universidad Católica del Perú, Instituto de Estudios Peruanos, 2006), 51.

20 Jaime Borja Gómez, «Idolatría, tiranía y barbarie. La construcción del indígena en una crónica indiana», en Passeurs, mediadores culturales y agentes de la primera globalización en el Mundo Ibérico, siglos XVI-XIX, ed. Scarlett O'Phelan y Carmen Salazar-Soler (Lima: Editorial Pontificia Universidad Católica del Perú, 2005), 34.

21 «La retórica es el arte de elaborar discursos gramaticalmente correctos, elegantes y sobre todo, persuasivos. [...] La retórica antigua abarcó tres géneros de discurso oratorio: el forense o judicial o jurídico; el deliberativo o político y el demostrativo o panegírico, epidíctico, economiástico o de circunstancias, que describe (con alabanza y elogio o censura y vituperio) personas o cosas y en el que se desarrolla la figura de pensamiento llamada evidencia (tipo de descripción)». Helena Beristáin, Diccionario de retórica y poética (México: Porrúa, 1997), 426-427. quiere presentar al lector. Había reglas específicas que definían cómo se debía llevar a cabo la descripción de paisajes, personas y acciones de acuerdo con lo que, en cada caso, se quisiera demostrar, por lo que «el hecho histórico se supeditaba a los actos morales que se desprendían de él para que se pudiera cumplir con el objetivo de enseñar $y$, fundamentalmente crear imágenes en el lector». ${ }^{22}$

La segunda figura retórica utilizada por los cronistas del siglo XVI era el pathos, la recreación emotiva, mediante la cual se apunta a generar apoyo o rechazo por parte del lector: empatía por los virtuosos y antipatía por los viciosos. En este ánimo, las categorías de argumentación tenían la finalidad de presentar lo que era digno de alabanza o de vituperio; es decir, un cuadro de vicios y virtudes. Por ello, el tercer recurso es la comparatio, mecanismo mediante el cual se contrastan los actos morales dignos de ser imitados con aquellos encarnados por el tirano, quien ejemplifica todos los vicios. En aras de lograr con eficacia la oposición y la identificación del lector con el modelo de lo deseable se usaron esquemas que resultaban útiles para la descripción de las personas. «Para el efecto se proponía seguir el orden de alabar el alma, el cuerpo y las cosas exteriores». ${ }^{23}$ Para el alma se usaba el esquema de las virtudes cristianas, la fuerza del ingenio, la memoria y la destreza; los bienes del cuerpo eran la valentía, la fuerza y la belleza; y los bienes externos eran la patria, la riqueza y el honor. En cambio, los vicios se articulaban alrededor de la soberbia, pero entre los comportamientos más reprobados estaban, además de los siete pecados capitales, la maldad, la cobardía, la traición.

E1 modelo de las virtudes se asoció directamente a la moralidad que debía observar el buen gobernante. Así lo plantea Pedro de Rivadeneira en su Tratado de la religión y virtudes que debe tener el principe cristiano, publicado en 1595, del que retomo la definición de las cuatro virtudes cardinales, aquellas que son el principio

22 Borja Gómez, «Idolatría, tiranía y barbarie», 44-45. 23 Borja Gómez, «Idolatría, tiranía y barbarie», 48. 
de otras virtudes, o que las contienen en sí. La primera virtud cardinal es la justicia, aquella que «da con igualdad á cada uno lo que es suyo»; ${ }^{24}$ la templanza, que enseña a moderar los apetitos desenfrenados de los sentidos; ${ }^{25} \mathrm{la}$ prudencia, "guía y maestra de todas las virtudes morales del príncipe cristiano»; ${ }^{26}$ y la postrera virtud es la fortaleza, porque «es el sello y guarda de todas, y las que las tiene debajo de su amparo y defensa», ${ }^{27} \mathrm{y}$ porque prepara para arduas y peligrosas tareas, no por ambición sino por el bien público. Las virtudes teologales, cuyo objeto es Dios, son la fe, la esperanza y la caridad. De las virtudes cardinales se derivan otras tantas como: la humildad, la clemencia y la mansedumbre, la diligencia, la misericordia, la castidad, la sobriedad, la liberalidad y la magnificencia.

La Nueva corónica y buen gobierno responde en buena medida a esta intención de generar en el lector empatía por los indios cristianos ultrajados y antipatía por los españoles que no temen a Dios ni a la justicia; sin embargo, el modelo no se reduce a ello, pues dada la marginalidad de Guaman Poma, así como su linaje respecto a los gobernantes cusqueños, el autor, a pesar de reconocer la virtud de la fortaleza en los gobernantes incas, se ve obligado a describir a algunos de ellos y a sus respectivas esposas conjugando la fealdad, los vicios y la idolatría. Tal es el caso del quinto Inca,

24 Pedro de Rivadeneira, «Tratado de la religión y virtudes que debe tener el príncipe cristiano para gobernar y conservar sus estados, contra lo que Nicolás Maquiavelo y los políticos de este tiempo enseñan», en Obras escogidas con una noticia de su vida y juicio crítico de sus obras de Vicente de la Fuente (Madrid: Atlas, 1952), 526. La justicia «Significa también virtud y bondad en las costumbres», Real Academia Española, Diccionario de autoridades (Madrid: Gredos, 2002) [facsímil de Diccionario de la lengua castellana, (Madrid: Francisco del Hierro, 1726)].

25 «Virtud, que modera los apetitos, y uso excessivo de los sentidos, sujetandolos à la razon». Real Academia Española, Diccionario de autoridades.

26 Rivadeneira, «Tratado de la religión y virtudes», 552. La templanza «enseña a discernir y distinguir lo que es bueno o malo para seguirlo o huir de ello». Real Academia Española, Diccionario de autoridades.

27 Rivadeneira, «Tratado de la religión y virtudes», 567. La fortaleza «dispone el ánimo para las cosas terribles y amargas acciones heroicas, haciéndole que ni tema cobardemente, ni temerariamente se atreva, sin que por esto se aparte de ejecutar lo que conoce es puesto en razón, por difícil, arduo y terrible que sea». Real Academia Española, Diccionario de autoridades.
Capac Yupanqui, de quien dice: «medianito de cuerpo, cara larga, auariento, poco sauer, el que enuentó a brindar a su padre el sol y mandó dar de comer a los ýdolos y uacas». ${ }^{28} \mathrm{Gua}-$ man no solo emite juicios adversos sobre los incas, también despacha a algunos indios coloniales. Reconoce una gran variedad, desde los buenos cristianos hasta aquellos que «erán haraganes y mentirosos, grandícimos borrachos y jugadores, ladrones, traydores, enubidente, tomando el costumbre de los malos cristianos españoles». ${ }^{29}$ Aunque en este caso muestra la mala influencia de los españoles, Guaman asocia a los indios con la corrupción moral. Algo semejante pasa con los españoles, pues a pesar de lo abrumadoras que resultan las imágenes que presentan sus acciones de crueldad, también tienen matices, y Guaman reconoce a aquellos que, como buenos cristianos, se preocupan por los indios: por ejemplo, algunos religiosos o los españoles y españolas que nacieron en Castilla, de quienes dice: «son de mucha honrra y bien dotrinados. Tienen todo entero fe de cristiano y tienen esperansa y cari$d a d$, amor de prógimo y tiene justicia y letra de Dios. [...]. Y oyen el santo euangelio amorosos, caritatibos, umildes. Más quieren ser pobres que rricos». ${ }^{30}$

Precisamente porque nadie escapa, por raza, a la tentación de los vicios y pecados, Guaman mantiene, a lo largo de su obra, el llamado general a todos los «cristianos lectores» a dejar el pecado y la mentira y a dar el buen ejemplo. Así podemos afirmar que la generalización sobre los indios andinos como virtuosos y de todos los españoles como viciosos y poco temerosos de Dios es insuficiente para explicar la obra de Guaman Poma.

Además del modelo retórico de la crónica, se ha propuesto que la obra de Guaman pudo haber recibido la influencia de otros géneros como el del denominado «consejería real»o

28 Guaman Poma de Ayala, Nueva corónica y buen gobierno, f. 101 [101]. La imagen de este Inca incluye a un demonio alado del lado superior derecho de la lámina.

29 Guaman Poma de Ayala, Nueva corónica y buen gobierno, f. 872 [886].

30 Así se ve en la descripción que hace de algunas órdenes eclesiásticas como los franciscanos, jesuitas y ermitaños. Guaman Poma de Ayala, Nueva corónica y buen gobierno, f. 629 [643]-636 [650]. 
regimine principum, que supone que el príncipe debe ser el modelo de virtudes para sus súbditos, así como recibir recomendaciones de un consejero. ${ }^{31}$ Bajo este paradigma, la Nueva corónica y buen gobierno cumple con esta característica, pues el autor se concibe a sí mismo como el consejero del Rey Felipe III, e incluso llega a recrear y dibujar una entrevista entre ambos, donde el monarca le hace una serie de preguntas para el mejoramiento del gobierno peruano. ${ }^{32}$ Sin embargo, este apartado es relativamente corto con respecto al resto de la segunda parte de la obra dedicada al buen gobierno. Es decir, el autor abandona, como eje rector, el forjar al Rey como modelo moral de sus súbditos y se inclina, a cambio, por un llamado a todos a temer a Dios y a la justicia. De este modo, no se trata de influir sobre el comportamiento moral del soberano, sino de requerir su intervención política en los asuntos del virreinato peruano, y la sugerencia de nombrar a un consejero de confianza que, según Guaman, sería él mismo.

Por otro lado, encontramos a la «emblemática política», un género artístico que establece una relación intrínseca entre imagen y texto para transmitir un mensaje que, tradicionalmente, es de carácter moralizante; se conforma de ilustraciones alegóricas y un elemento textual que generalmente está en verso. ${ }^{33}$ "Por decirlo así, lo estético se pone al servicio de lo ético en un intento de razonamiento de los antiguos lugares comunes», ${ }^{34}$ es decir, de los cuadros de vicios y virtudes. No obstante, por cuestiones cronológicas es difícil postular la influencia directa de esta tradición en la obra de Guaman, ${ }^{35}$ pero es posible inferir que ambas participan

31 López-Baralt, Ícono y conquista, 293.

32 Guaman Poma de Ayala, Nueva corónica y buen gobierno, f. 961 [975].

33 La emblemata se refiere «sobre todo a tópicos y moralejas de la poesía del barroco, que contiene imágenes grabadas, con sus respectivas explicaciones en latín y con numerosos ejemplos». Beristáin, Diccionario de retórica y poética, 166.

34 Christian Bouzy, «El emblema: un nuevo lugar estético para los antiguos lugares éticos», Criticón, n. ${ }^{\circ} 158$ (1993): 36.

35 Es solo hasta el siglo XVII que la emblemática española convierte su carácter moral y religioso en político. El primer título de esta variante es el Príncipe perfecto y ministros aiustados, documentos políticos y morales, de Andrés Mendo, publicado en Salamanca en 1611. Fecha muy tardía como para haber influenciado la obra de Guaman Poma. López-Baralt, Ícono y conquista, 299. del principio tridentino de promoción de la comunicación visual para los manuales didácticos. En este sentido, lo que se trata de destacar aquí no son las fuentes directas del autor, sino que su obra se inscribe dentro de un contexto trasatlántico de modelos tanto poéticos como iconográficos que se articulan alrededor de la preocupación central de la Corona española y de la cristiandad: educar y moralizar a los súbditos.

Entonces es posible afirmar que, por la centralidad que adquieren las imágenes en la obra de Guaman Poma, al anteceder, en cada ocasión, al texto que declara el asunto ilustrado, por la combinación de imagen con texto dentro las láminas pictóricas y por la representación iconográfica de vicios y virtudes, la Nueva corónica habría respondido en primer lugar a una tradición retórica como figura narrativa propia de la historia; en segundo, a la producción de manuales de consejería para educar a los gobernantes, $y$ en tercero, a los preceptos antireformistas de Trento que aconsejaban el uso de imágenes para educar y formar buenos cristianos. Empero, las particularidades de la obra también la distancian de esas tradiciones. En primera instancia, la estructura de la obra, dividida en dos partes, resulta útil al autor para plantear una comparatio no solo entre los vicios $\mathrm{y}$ virtudes sino entre diferentes culturas, destacando los vicios de cada una de ellas.

Es decir, la Nueva corónica dedicada a la historia prehispánica andina, esboza un sistema de justicia implacable como uno de los aspectos más favorables de los incas, pero eso no impide al autor asociar a estos gobernantes con una serie de vicios, entre los que la idolatría se erige como el peor. De este modo no se trata de una asociación directa sobre incas virtuosos y españoles viciosos, pues si bien la segunda parte, el buen gobierno, es notablemente adversa a los españoles, y su denuncia puntual recorre cada cargo y da cuenta de nombres y apellidos de personajes, el autor no se permite condenar todo lo español, porque su subjetivación, para encontrar su lugar dentro del orden colonial, dependía de la asimilación de los esquemas de comportamiento y de los valores morales enseñados por la religión cristiana. 
La violencia, entre la justicia

y la soberbia

Si el modelo de vicios y virtudes no puede asociarse plenamente a la dicotomía entre indios y españoles, resulta aún más complicado distinguir, de entre todas las escenas de violencia que aparecen en la obra, aquellas que tienen la finalidad de representar virtudes y no vicios ni abusos. Es decir, en la medida en que Guaman asocia la justicia a la eficacia de los castigos como la única garantía de un buen gobierno, la violencia prima en las imágenes tanto de las virtudes como de los vicios. El siguiente grupo de imágenes fue seleccionado porque independientemente de estar articuladas alrededor del vicio de la soberbia o de la virtud de la justicia muestran imágenes de maltrato físico, cuyo sentido no es fácil determinar.

Por ejemplo, al ver la lámina titulada «COREGIDOR DE MINAS: CÓMO LO CASTIGA CRVelmente a los caciques prencipales los corregidores y jueses con poco temor de la justicia con deferentes castigos cin tener misericordia por Dios a los pobres» ${ }^{36}$ (Figura 1), es evidente la violencia ejercida por el español sobre diversos indios. Al leer el título se confirma que se trata de una crítica a la falta de templanza y a la prudencia del corregidor de minas para administrar los castigos, quien además es acusado de no temer a la justicia.

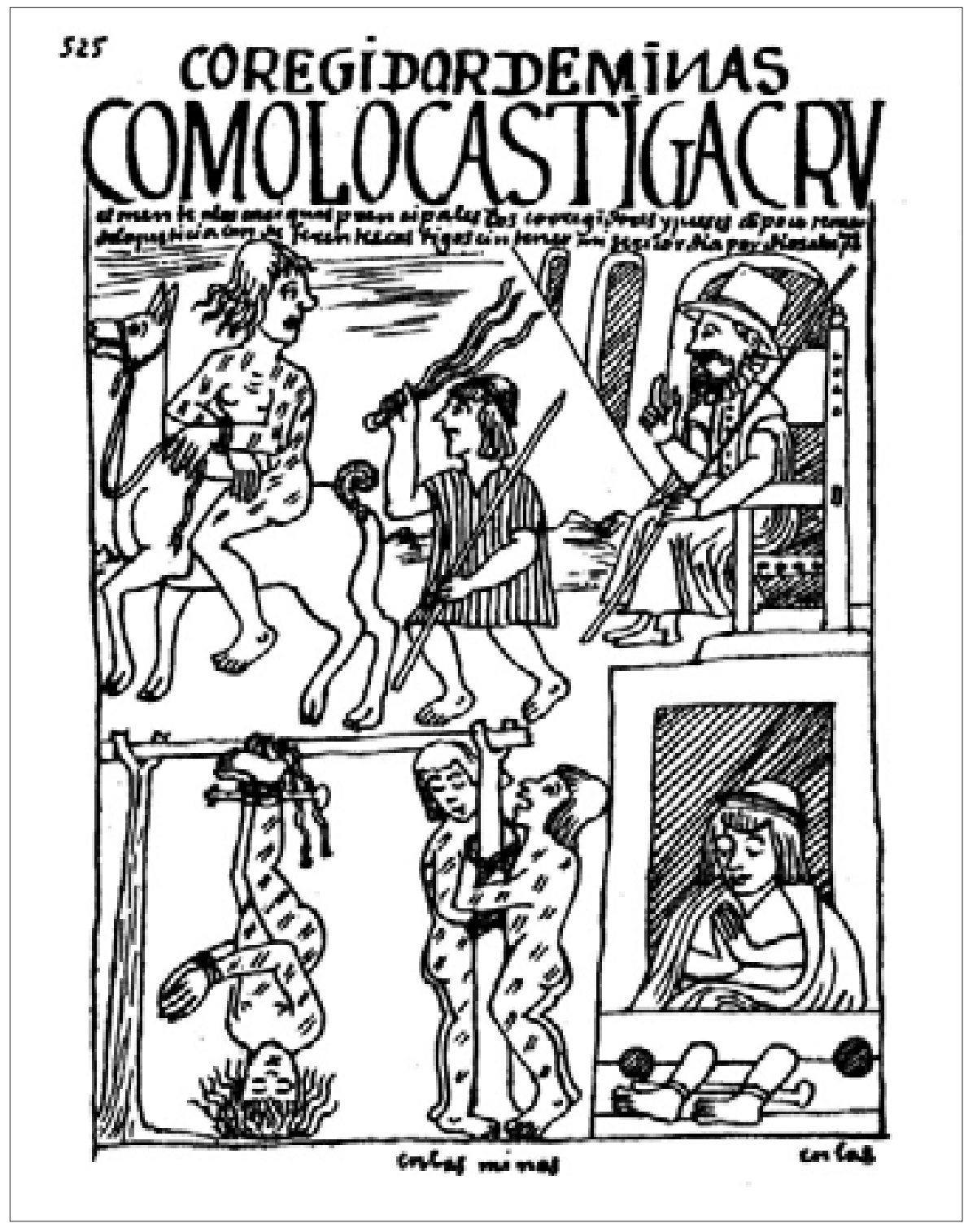

Figura 1.

Corregidor de minas castiga cruelmente a los caciques, f. 525 [529]. 
Figura 2.

Castigo a las adúlteras, f. 306 [308].

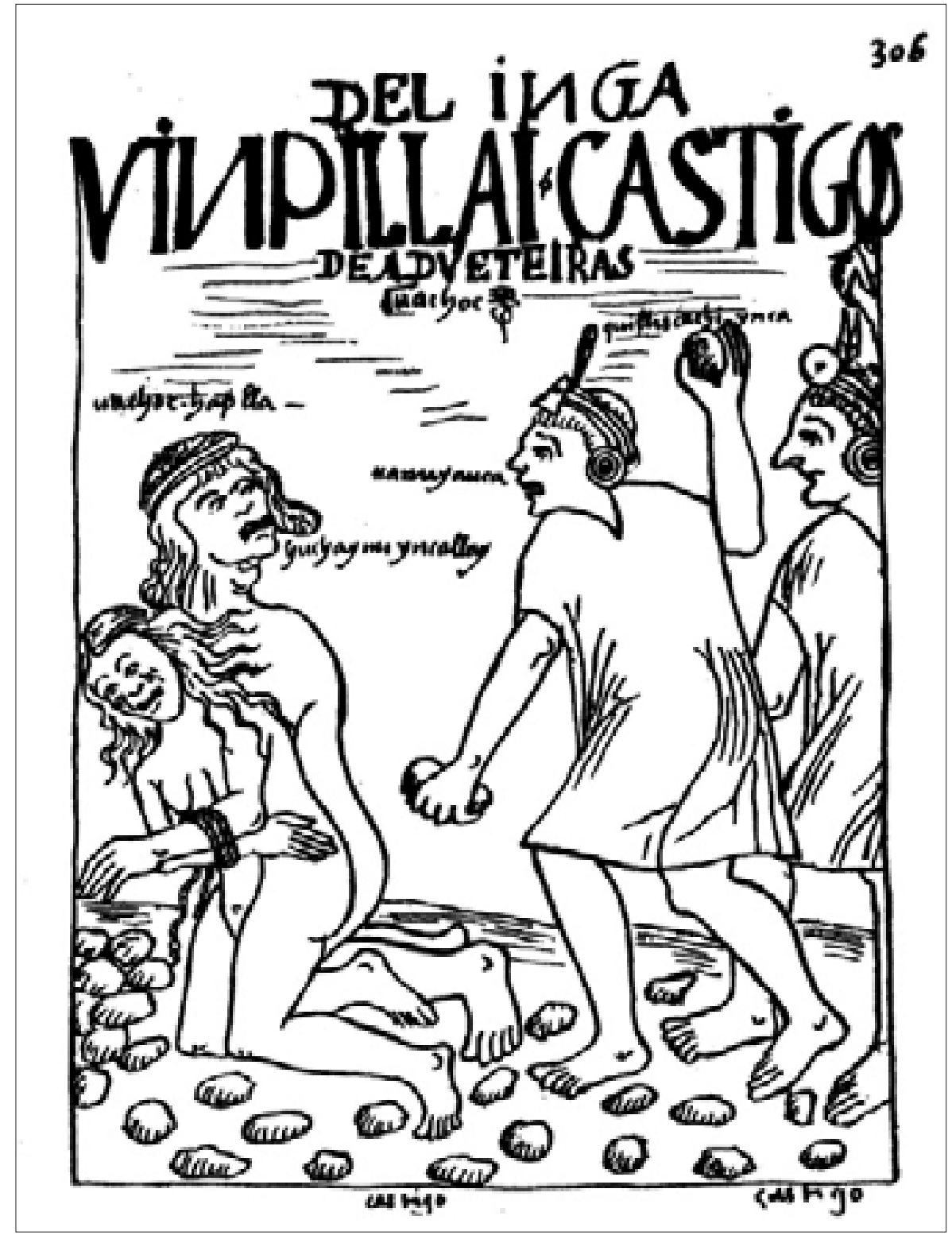

La justicia está representada para la época colonial por el Rey, a quien Guaman interpela en la obra. Hay, además, un par de elementos que escapan a la representación iconográfica: el personaje colgado de cabeza es, según el texto, un cacique principal, al que no es posible reconocer, pues está desnudo igual que aquel que sobre una llama es azotado por otro indio, y que - de acuerdo con Guaman - no es cacique principal. No obstante los detalles que se pierden al escindir la imagen del texto, su sentido resulta claro y casi unívoco: el corregidor es injusto en su trato con los indios. ${ }^{37}$

37 Desde el principio de la «lateralidad» esbozado por Carlos González, Hugo Rosati y Francisco Sánchez, la posición del funcionario
En cambio, cuando se compara con las imágenes tituladas: "VINPILLAI, CASTIGOS DE ADVLTERAS $»^{38}$ (Figura 2), «ANTA CACA, ARAVAI, CASTIGOS DE VÍRGENES ${ }^{39}$ (Figura 3),y «IAVAR PAMPA, CASTIGO, LOS QVE MATA CON PONZONA $»^{40}$ (Figura 4), encontramos tres

español del lado izquierdo de la lámina (derecho del lector) implica una interpretación negativa del funcionario, en tanto subvierte las jerarquías espaciales andinas. Así, la disposición de las figuras denota un juicio moral que condena los abusos perpetrados. Guaman Poma. Testigo del mundo andino (Santiago: LOM, 2003), 345.

38 Guaman Poma de Ayala, Nueva corónica y buen gobierno, f. 306 [308]. 39 Guaman Poma de Ayala, Nueva corónica y buen gobierno, f. 308 [310]. 40 Guaman Poma de Ayala, Nueva corónica y buen gobierno, f. 310 [312]. HANPIyoc collayoc runa uatoc [los que dañan a los hombres con venenos y ponzoñas]. 


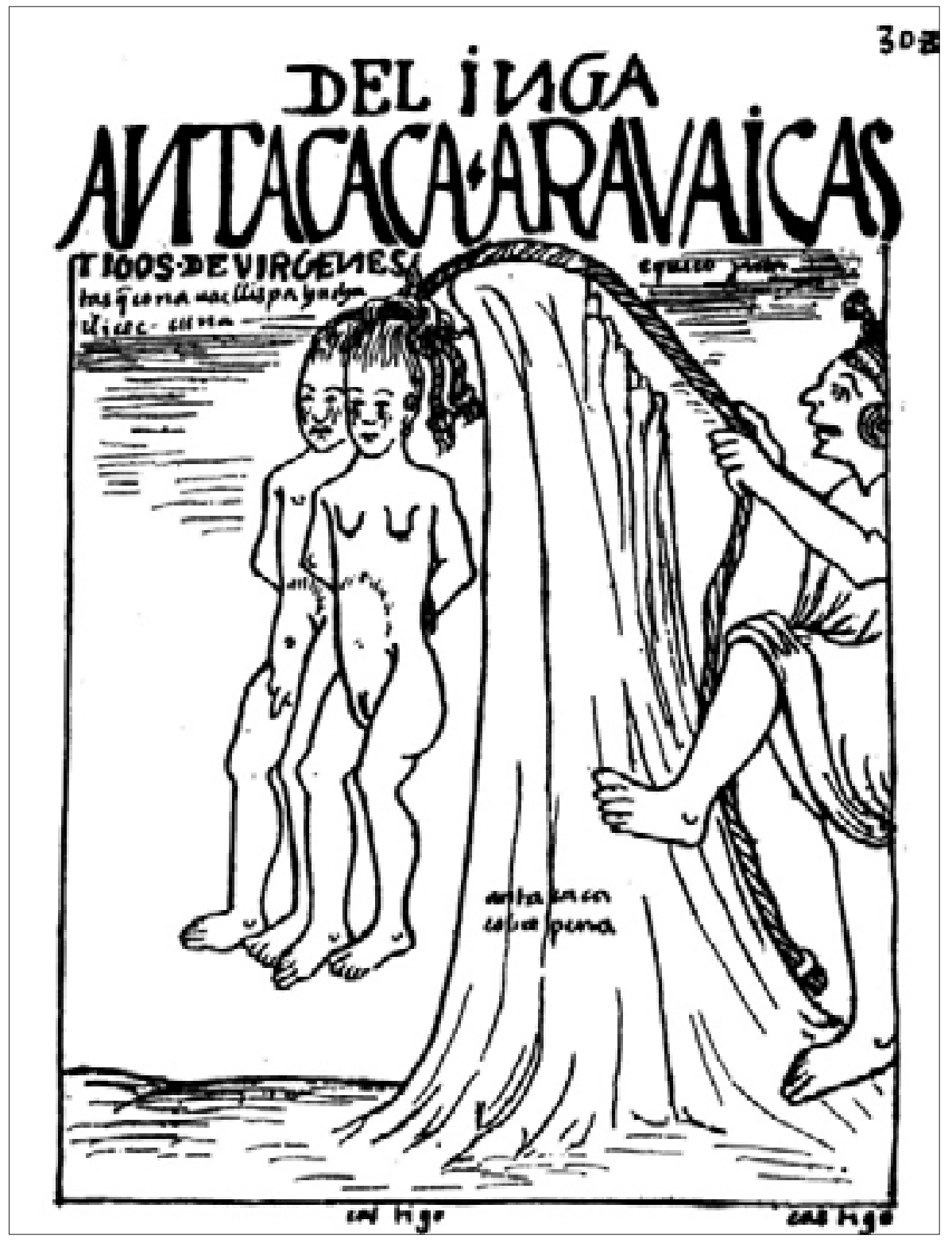

escenas particularmente violentas, que, como la anterior, muestran castigos, pero en este caso establecidos por los incas para sancionar a los adúlteros, a las vírgenes que rompen la castidad y a los «hechiceros». Las tres escenas tienen algo en común: todas ellas muestran maltratos físicos $y$, aunque en las tres aparece, en la base y fuera del rectángulo, la palabra castigo, no en todas es clara la infracción perseguida, por lo que se debe acudir a las anotaciones dentro de la lámina en donde se mencionan los delitos. Además, solo se puede conocer la condena definitiva a través del resto de notas, la mayoría de ellas en quechua, en donde se aclara que en todos los casos la pena es la muerte, aunque en todos ellos los suplicios previos sean específicos. Si bien la nota al pie nos aclara que se trata de penas a transgresores de la ley, poco nos advierte respecto a la justicia o injusticia de la condena.

Ser azotado, apedreado, golpeado, colgado, desterrado o la muerte misma eran solo algunos de los castigos incas que Guaman enlista. Había atenuantes para castigar el adulterio si el hombre había sido forzado por la mujer, y en lugar de la muerte solo se le condenaba a ser azotado y al destierro perpetuo; mientras que a la mujer forzada se le daban doscientos azotes y se le enviaba a la "casa de las escogidas» para servir ahí el resto de su vida. A los donceles y doncellas que no guardaren la honra los colgaban vivos de los cabellos hasta su muerte. Los hechiceros, 
Figura 4.

Castigo a los que matan con ponzoña, f. 310 [312].

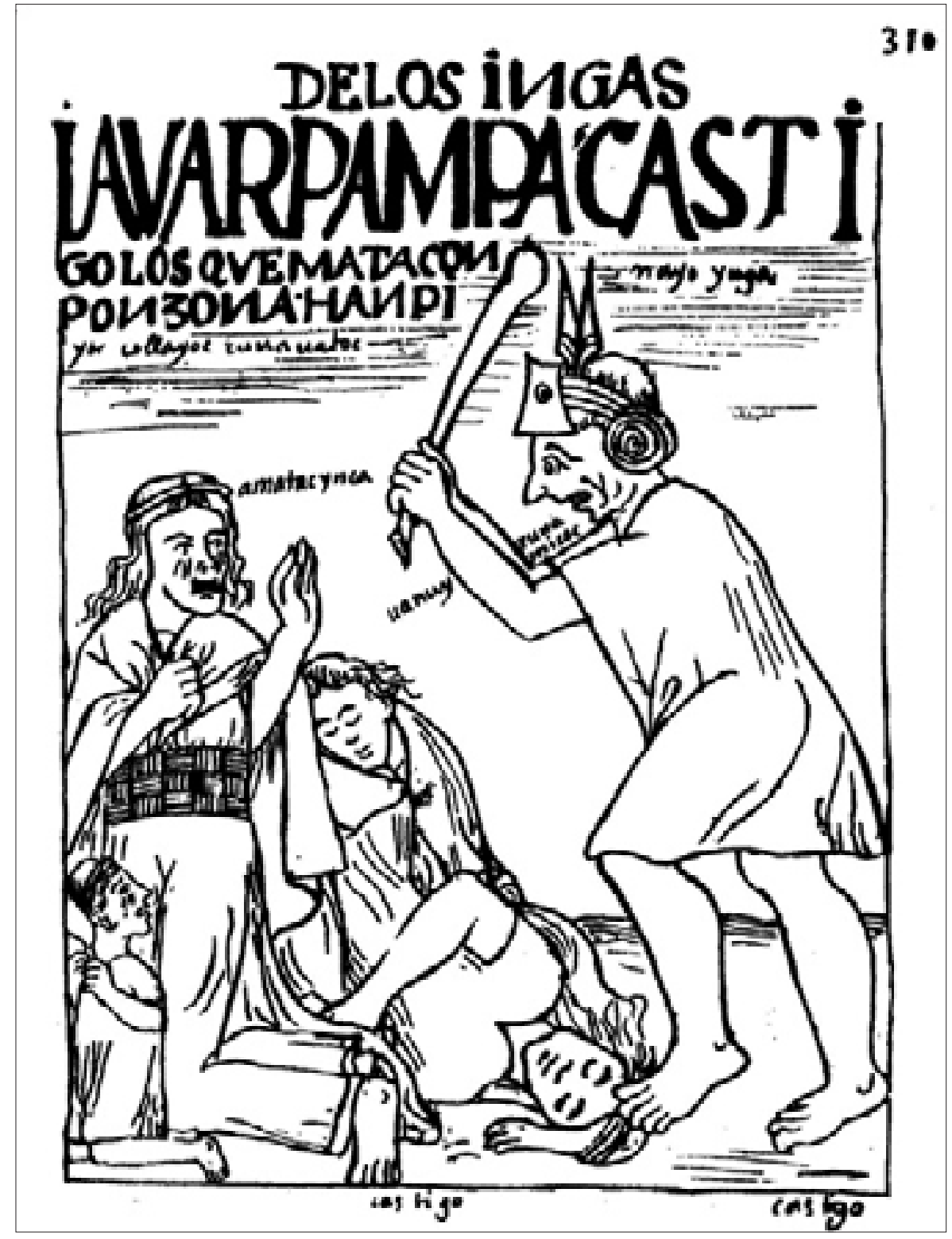

curanderos y adivinos morían junto con toda su casta, no se les enterraba y eran devorados por los cóndores. ${ }^{41} \mathrm{La}$ lista de castigos sigue en el texto por lo menos durante tres folios más y su diversidad y crueldad son notables. Guaman enumera castigos para los señores y señoras principales en falta, para las mujeres pobres, para los borrachos, para los caballeros, para los mentirosos, para los perezosos y puercos, para los jugadores, para los desobedientes y mal criados, para los muchachos y muchachas, para los asesinos y para los traidores a la Corona. ${ }^{42}$ De

41 Guaman Poma de Ayala, Nueva corónica y buen gobierno, f. 311 [313] 42 Guaman Poma de Ayala, Nueva corónica y buen gobierno, f. 311 [313]-314 [316]. modo que se construye una lista de vicios y perversiones fundados en los pecados capitales; esto es, los incas aparecen castigando vicios derivados de la pereza, la gula y la lujuria, todos ellos condenados por la moral cristiana. En todo caso, Guaman incluye la larga lista de vicios para detallar la brutalidad de los castigos que correspondían a cada uno.

Puesta la crueldad de estos castigos, se condenaría implícitamente a los gobernantes incas de otros pecados como la ira, la soberbia y la falta de templanza y misericordia, y se les descalificaría como buenos gobernantes. Sin embargo, Guaman decide justificar los castigos y así privilegiar la impartición de justicia para garantizar el orden social. Así lo declara el autor cuando afirma que: 


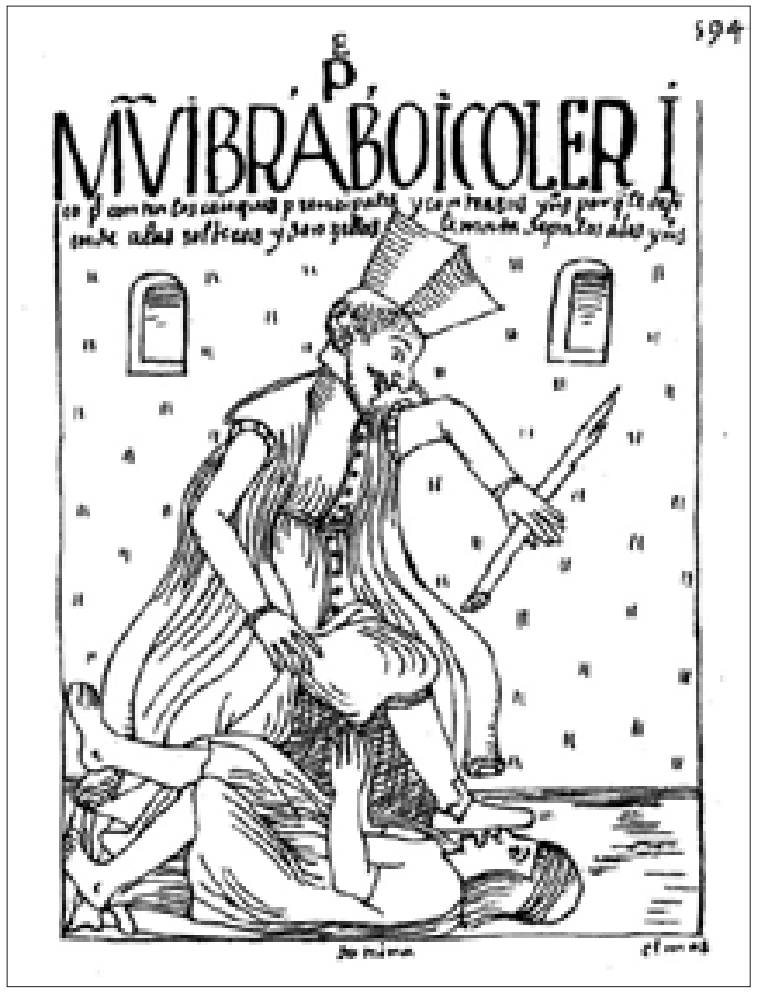

Figura 5.

Muy bravo y colérico padre contra los caciques principales, f. 594 [608].

ancí andaua la tierra muy justa con temoridad de justicia y castigos y buenos egenplos. Con esto parese que eran ubidente a la justicia y al Ynga y no auía matadores ni pleyto ni mentira ni peticiones ni proculadrones $[$ sic $]$ ni protetor ni curador enteresado ni ladrón, cino todo uerdad y buena justicia y ley. ${ }^{43}$

Resulta evidente que Guaman subraya la diversidad y severidad de los castigos infligidos a los transgresores para presentar la imagen de un gobierno que garantizaba el buen comportamiento de sus gobernados a través del temor a la justicia. Aclama a los Yngas y demás funcionarios públicos por haber sido temidos y servidos. En cambio, cuando se trata de reprochar los malos comportamientos de los españoles, Guaman utiliza como muletilla la frase: «Y no temen a Dios ni a la justicia», ${ }^{44}$ reafirmando su noción de esta virtud, entendida como sinónimo de castigo merecido y garantía del buen gobierno.

Esta estrategia supedita sin miramientos la imagen del buen príncipe cristiano a la violencia de los castigos. Este enfoque cuadraba a la perfección

43 Guaman Poma de Ayala, Nueva corónica y buen gobierno, f. 307 [309] 44 Guaman Poma de Ayala, Nueva corónica y buen gobierno, f. 500 [504]. con la imagen que el autor pretendía dar de los incas: la de gobernantes advenedizos e idólatras y, en ese sentido, ilegítimos y tiránicos, aunque paradójicamente justos. La complicada imbricación entre los castigos corporales y la impartición de justicia, o entre un buen gobierno y la tiranía, difícilmente se podría desprender de un análisis independiente de las imágenes. Por ejemplo, en términos gráficos el «Quinto Castigo» de los incas a los hechiceros (Figura 4) presenta una escena de apaleamiento muy parecida a las siguientes cuatro láminas, cuya intención es justamente la contraria: demostrar la soberbia y, a partir de ella, la injusticia.

En la lámina 594 [608], aparece un sacerdote «muy bravo y colérico» que arremete con un palo en contra de los caciques principales y demás indios (Figura 5). En el dibujo del folio 706 [720] se contrasta la «paciencia y amor de Jesucristo los buenos negros y negras» con la bellaquería de su amo, cuando este agarra a palos a una pareja de esclavos, y demuestra, según el autor, que adolece de caridad y de amor al prójimo (Figura 6).

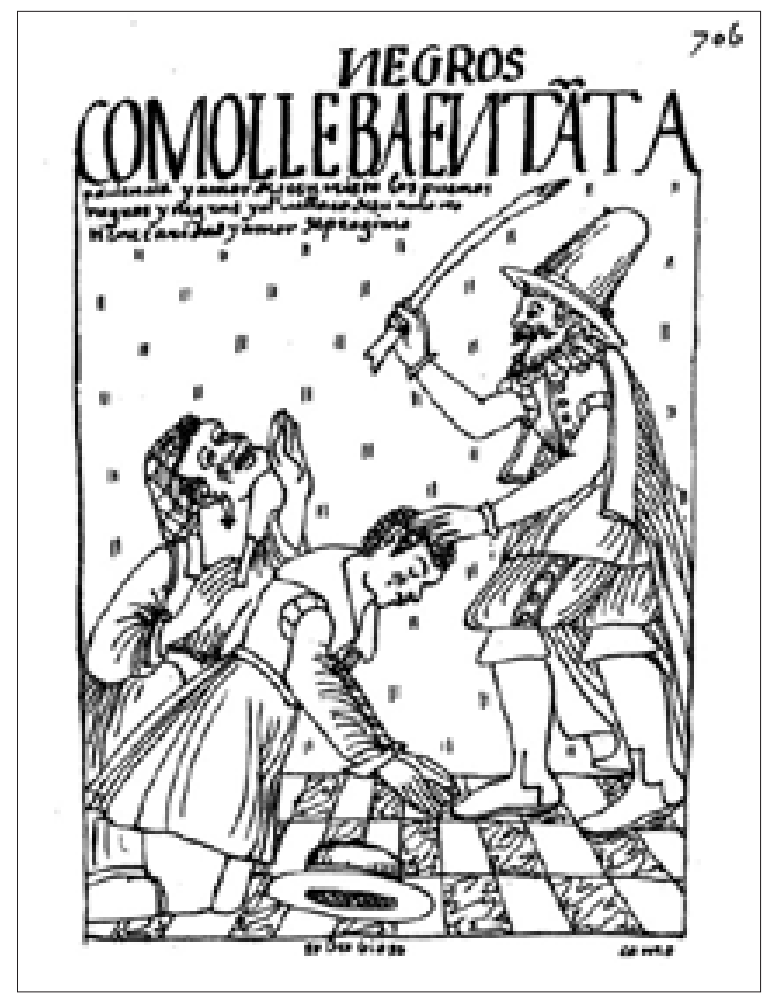

Figura 6.

Cómo lleva en tanta paciencia y amor de Jesucristo los buenos negros y negras, f. 706 [720]. 
Figura 7.

Que no obedece a su padre, f. 874 [888].

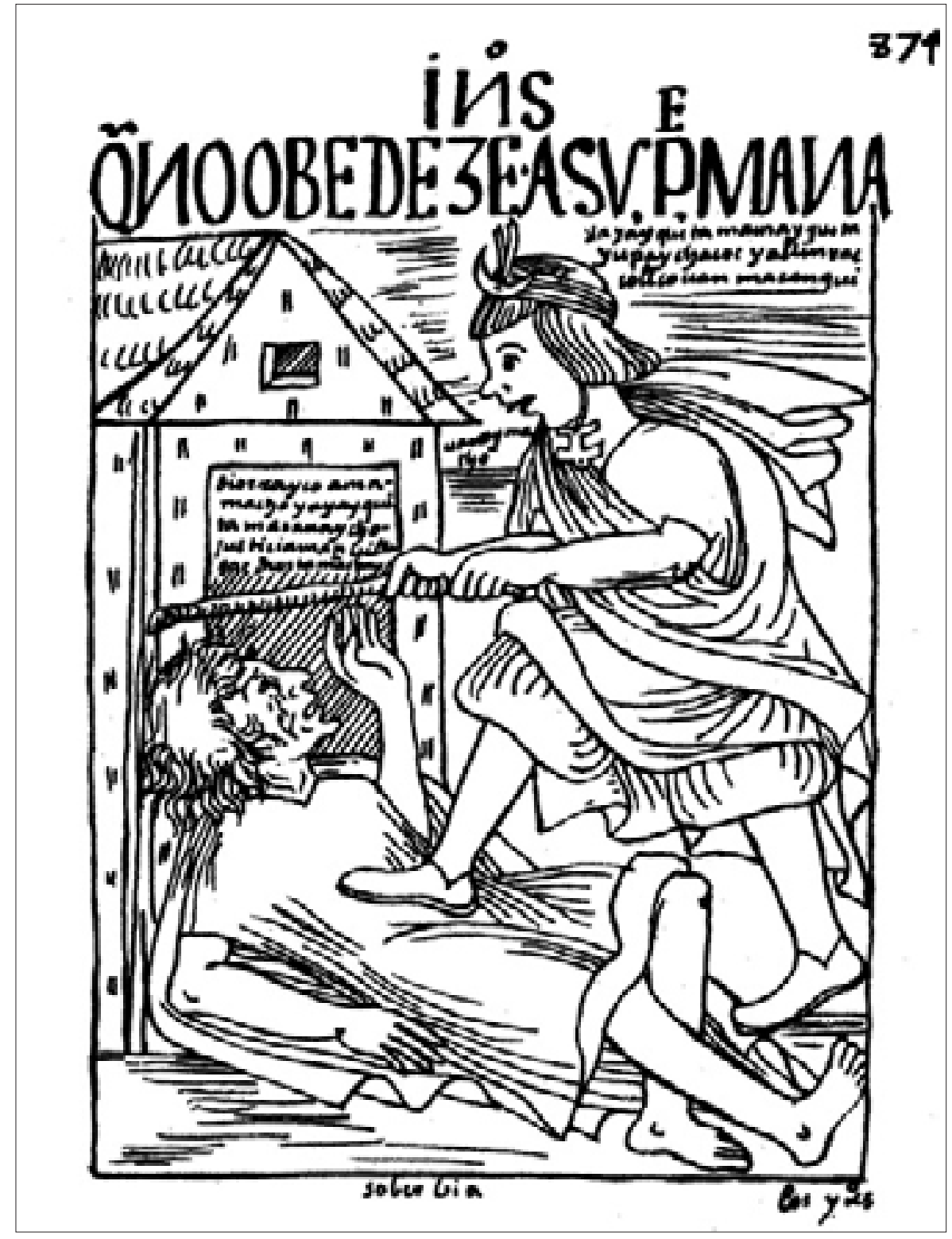

La siguiente lámina, 874 [888], lleva por título: «Q[UE] NO OBEDEZE A SV P[ADR] E» (Figura 7), lo que sugiere que puede tratarse de un castigo por desobediencia, y en ese caso sería justa la sanción. Sin embargo, en la imagen el indio joven apalea al anciano. La leyenda en quechua dentro de la imagen aclara que el joven no ha honrado a su padre y que lo ha golpeado con un palo. ${ }^{45}$ Pero el sentido más profundo de la representación, que es culpar de los vicios de los indios al mal ejemplo de los españoles, se encuentra en el texto, donde Guaman señala que si el indio violentaba a su padre era por falta de doctrina. De este modo el autor presenta el desacato a uno de los diez mandamientos: honrar a los padres, como consecuencia de que los indios «no son dotrinados ni castigados». Además, nos advierte que el viejo amenazó a su hijo con delatarlo ante la justicia, lo que nos conduce a pensar que Guaman ambicionaba la conformación de un sistema de justicia colonial eficaz, ya que en la situación que se vivía hasta entonces, los indios «no quieren guardar los mandamientos de Dios ni la ley de los antepasados». ${ }^{46}$ 


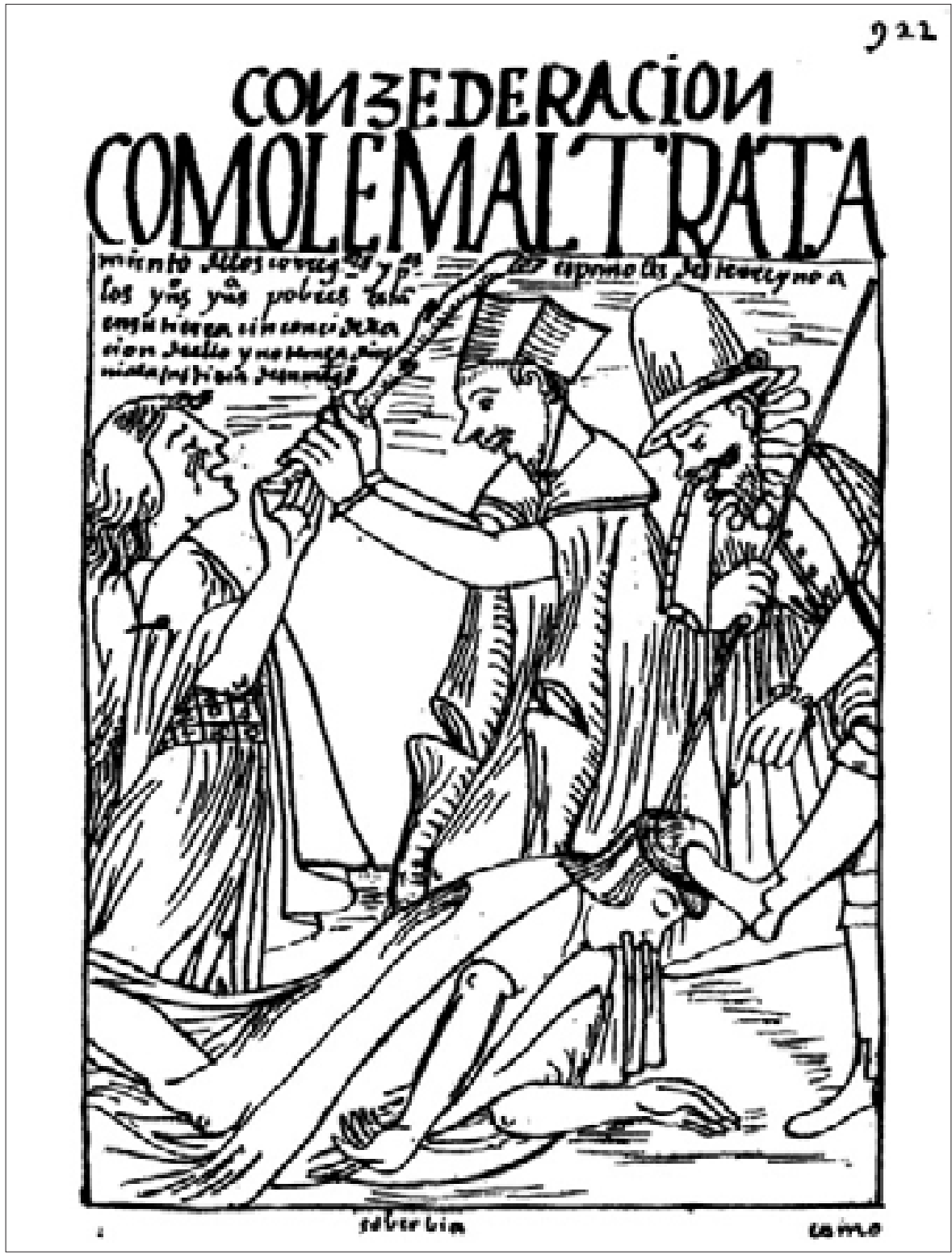

Finalmente, tenemos que en el folio 922 [936] Guaman sintetiza en una sola imagen la soberbia de los funcionarios españoles, tanto civiles como eclesiásticos, al dibujar a un corregidor que aparece golpeando con una vara a un indio mientras lo patea y a un sacerdote que con un palo amenaza a una india que llora. El título dice: "CÓMO LE MALTRATAmiento $[$ sic $]$ de los corregidores y padres españoles deste rreyno a los yndios, yndias pobres. Están en su tierra cin concideración de ello y no teme a Dios ni a la justicia de su Magestad ${ }^{47}$ (Figura 8). En esta lámina, la disposición de las figuras

47 Guaman Poma de Ayala, Nueva corónica y buen gobierno, f. 922 [936].
Maltratamiento de los corregidores y padres españoles a los indios, indias pobres, f. 922 [936]. coincide con colocar a los agresores del lado derecho, pero el clérigo golpea a la mujer y el corregidor al varón, con lo que el autor representa la idea de que «es enemigo mortal de los yndios los dichos corregidores y enemigo mortal de las yndias los dichos padres y curas», ${ }^{48}$ pues el amancebamiento, pecado de lujuria, era cometido por los clérigos con las indias. Sin embargo, en la imagen no aparece el resto de la explicación en la que Guaman denuncia que son más enemigos de los caciques principales. En los cuatro casos, como en el castigo a la hechicería, la acción es violenta, se trata de golpes con 
Figura 9.

Castigo, justicia, Sancay, Inquisición, f. 302 [304].

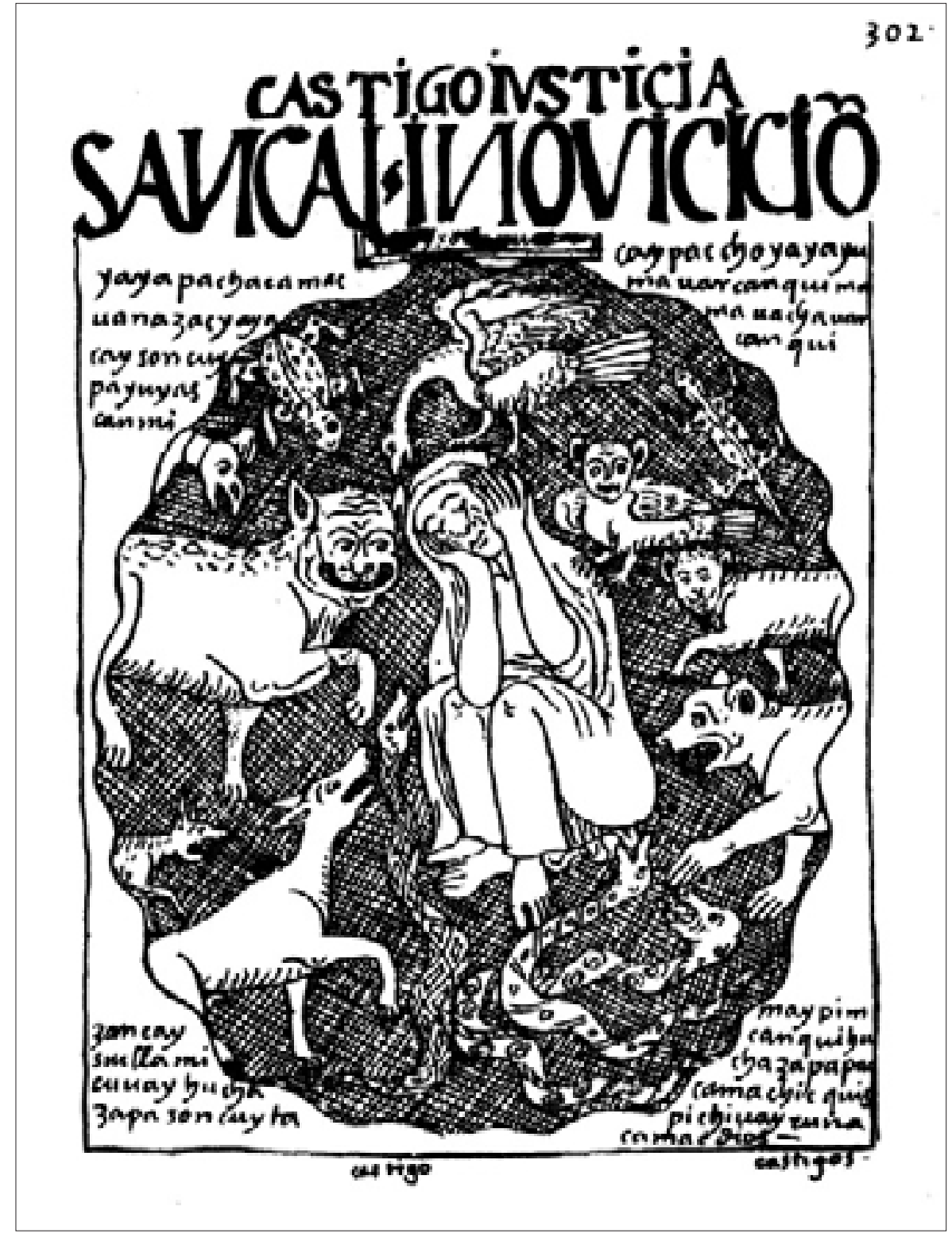

un palo o garrote; pero si a pesar de la semejanza iconográfica, en las últimas cuatro imágenes la nota al pie dice «soberbia», y con ello guía la interpretación del espectador hacia el vituperio, en la imagen del Quinto castigo inca (Figura 4), no hay suficientes elementos para colegir que lo que está ahí representado es un acto de justicia. Cabe señalar que, de las escenas aquí presentadas, el castigo inca es el único que conduce a la muerte del acusado y a la de toda su estirpe. Así, vemos que Guaman asocia la soberbia a la ira, como en el caso del padre colérico, pero también con la falta de caridad y de amor al prójimo, además lo contrasta con la paciencia y amor a Dios de los esclavos que aguantan la bellaquería de sus amos.
Con estos ejemplos reitero la imprescindible necesidad de acudir al texto para una hermenéutica de las imágenes, pero también perfilo un nuevo cuestionamiento sobre los motivos que tiene el autor para discernir qué informaciones anota en quechua dentro de la lámina y los detalles que desglosa en castellano, fuera de la lámina y a través del texto.

Pero, sin duda, el mejor ejemplo de la dificultad de separar las imágenes del texto que las acompaña originalmente en la obra, es la comparación de dos láminas que son iconográficamente semejantes en sus dibujos, pero con sentidos radicalmente distintos. La primera es un símbolo del orden y la justicia prehispánicos, pues 


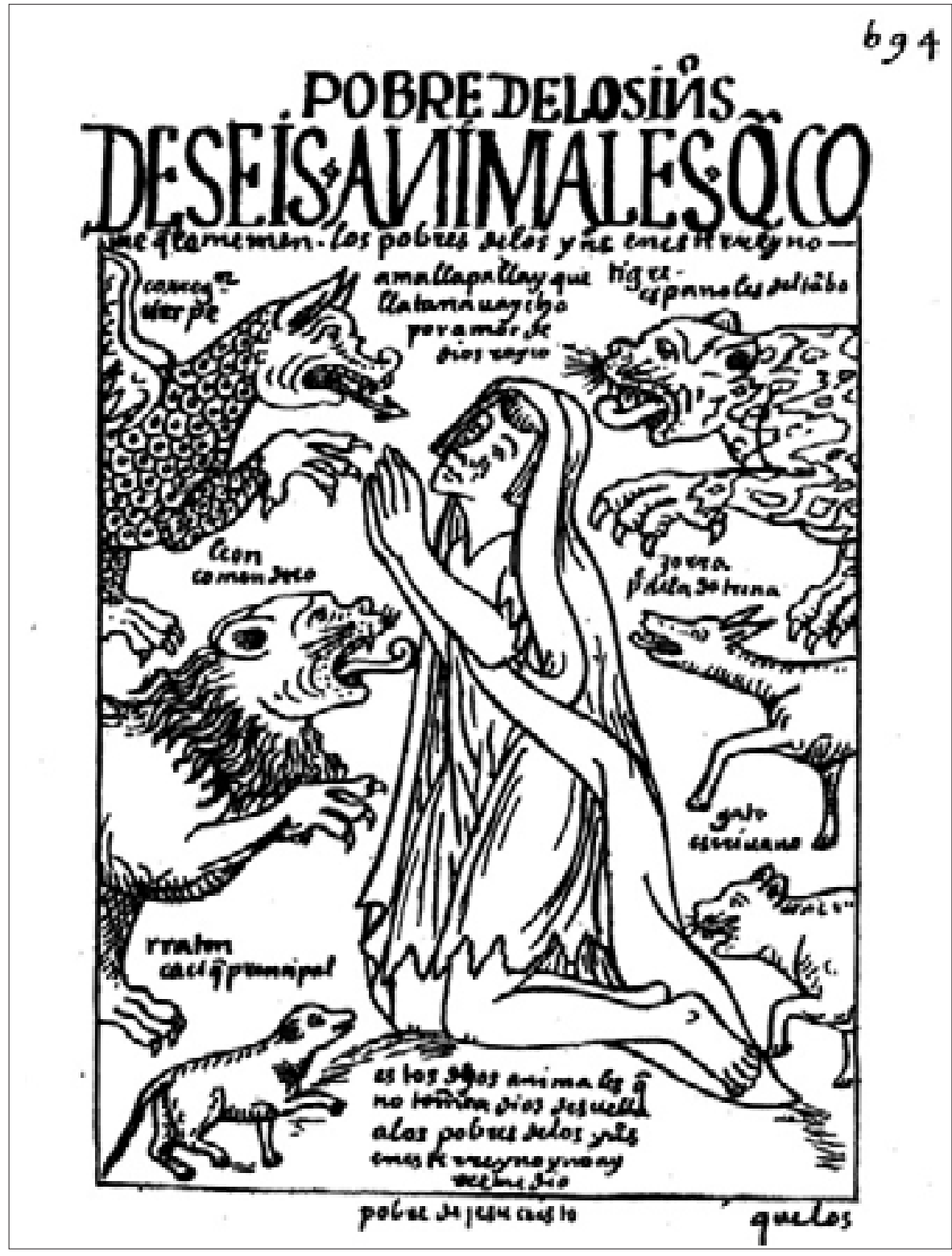

representa una cárcel inca como símbolo de la justicia que primaba durante su gobierno. La segunda, es una alegoría de la desesperada situación que vivían los pobres indios a expensas de los feroces funcionarios españoles.

En ambos dibujos es posible ver a una persona que llora y que es asediada por una diversidad de animales, y hay una desdicha implícita. Una diferencia fundamental es que la primera tiene el fondo oscurecido y no así la segunda, lo que sugiere un ambiente cerrado. En la segunda, la actitud de la persona es de súplica mientras que en la primera parece de resignación.

La primera imagen, folio 302 [304], inaugura el capítulo de la «IUSTICIA y castigos y preciones y
Figura 10.

Pobre de los indios: de seis animales que comen que temen, f. 694 [708]. 
corruptelas, y la relación con los indios. Por ello, la imagen titulada «pobres de los indios» aparece como la síntesis de todo ese recorrido.

Las dos láminas están repletas de anotaciones: en la primera, el título sancai, que quiere decir "cárcel perpetua», se acompaña de una leyenda que asocia al castigo y a la justicia con la Santa Inquisición, el resto de las anotaciones están en quechua y presentan una especie de plegaria de contrición y penitencia:

Padre creador del mundo, voy a escarmentar.

Padre, es la memoria de mi corazón.

¿Es para esto que me engendraste, padre, y me pariste, madre?

Cárcel, cómeme de una vez este mi corazón pecador. ¿Dónde estás, creador del pecador? Creador del hombre, Dios, sálvame. ${ }^{50}$

Estas anotaciones permiten al lector dirigir sus empatías, pues, por un lado, asocian el rigor del castigo inca al de la Inquisición, legitimando ante el lector cristiano las prácticas incas. Por otro lado, en la plegaria se presenta el arrepentimiento del cautivo como resultado deseable del encierro y afín al de otros castigos impuestos por el Santo Oficio.

En la segunda imagen, el título «POBRE DE LOS IN[DI]OS: DE SEIS ANIMALES Q[VE] COME que tememen [sic] los pobres de los yndios en este rreyno» se complementa también con una suerte de plegaria en quechua que dice: «No me despojen por amor de Dios; te voy a dar más. Por amor de Dios». ${ }^{51}$ En la base de la imagen aparece otra frase: «Estos dichos animales, que no temen a Dios, desuella a los pobres de los yndios en este rreyno y no ay rremedio. Pobre de Jesucristo». Además, junto a cada una de las bestias aparece su nombre asociado a un cargo político de la administración virreinal: sierpecorregidor, tigre-españoles del tambo [mesón], león-encomendero, zorra-padre de la doctrina, gato-escribano y ratón-cacique principal. ${ }^{52}$

La imagen de la cárcel es el símbolo del peor de los castigos incas; comparada con la Inquisición, es descrita como una construcción subterránea con

50 La traducción es de Jorge Luis Urioste, misma que se ofrece en la edición digital. Guaman Poma de Ayala, Nueva corónica y buen gobierno, f. 302 [304].

51 Guaman Poma de Ayala, Nueva corónica y buen gobierno, f. 694 [708].

52 Guaman Poma de Ayala, Nueva corónica y buen gobierno, f. 694 [708]. toda suerte de animales («serpientes, colebras ponsoñosas, animales de leones y ticre, oso, sorra, perros, gatos de monte, buytre, águila, lichusas, zapo, lagartos»)..$^{53}$ Estaba destinada para castigar a los grandes delincuentes («los auca [enemigo], yscay songo [traidor], suua [ladrón], uachoc [adúltero], hanpioc [brujo], ynca cipcicac [murmuradores del Inka], apuscachac [soberbio], ${ }^{54}$ para que fueran comidos vivos, aunque el autor advierte que algunos de los recluidos no eran comidos aunque estuviesen dos días dentro, y de lograrlo, recibían el perdón del Inca y salían de allí. Así resulta una lista de los que, según el autor, eran los vicios más perseguidos por los incas y nueva cuenta tenemos que se trata de pecados igualmente condenados por la Iglesia. Pero quizás lo más importante de estas cárceles es que Guaman reconoce que, con el miedo provocado por semejante castigo, «no se alsaua la tierra, pues que abía señores desendientes de los rreys antigos que eran más que el Ynga. Con este miedo callauan». ${ }^{55}$ Es decir, Guaman desliza la centralidad de la justicia lograda mediante este mecanismo de castigo y la sustituye por la imposición del miedo como artilugio de unos gobernantes ilegítimos (los incas), para evitar la rebelión de los antiguos señores de esas tierras (los familiares de Guaman Poma, entre otros).

El temor también es el núcleo de la segunda imagen, donde el indio es amenazado constantemente por toda la estructura burocrática colonial. El temor es fundado, y se explica en el texto: el corregidor es bravo como la cierpes [sic] y roba la vida; el encomendero es bravo y feroz, no agradece ni perdona al pobre; el doctrinero, los licenciados y letrados son mañosos como zorras, roban haciendas, mujeres e hijas; el escribano acecha al indio como el gato al ratón, hasta cogerlo; a los españoles del tambo les temen los indios porque son como tigres bravos que los roban y golpean; de los caciques principales se teme que sea un indio bajo el que ocupe el cargo, porque cual ratones hurtan de día y de noche, sin que nadie lo sienta. «Y ancí destrúye en este rreyno a los pobres de los yndios y no ay rremedio». ${ }^{56}$

\footnotetext{
53 Guaman Poma de Ayala, Nueva corónica y buen gobierno, f. 303 [305]. 54 Llama la atención que, en la enumeración de los delitos castigados en esta cárcel, la mayoría de ellos se nombra en quechua. Guaman Poma de Ayala, Nueva corónica y buen gobierno, f. 303 [305].

55 Guaman Poma de Ayala, Nueva corónica y buen gobierno, f. 303 [305].
} 56 Guaman Poma de Ayala, Nueva corónica y buen gobierno, f. 695 [709]. 
En este caso, la relación entre texto e imagen es importante, porque se trata de una imagen alegórica que simboliza la destrucción del reino; de modo que Guaman pone en el centro al indio, como el pilar sobre el que debe sostenerse la viabilidad del virreinato. Pero si en la imagen se compara al cacique principal con un ratón, en apariencia el más inofensivo de todos los animales representados, en el texto se afirma que «los caciques prencipales que se hazen de yndio bajo, [...] le gasta de las comunidades y de sapci quanto puede, que cinifica mayor que todos los animales porque de día y de noche nunca para y no ay rremedio de los pobres yndios deste rreyno». ${ }^{57}$ Con ello, insiste en que la política de despojar a los legítimos caciques principales de sus potestades ha sido el epicentro del cataclismo administrativo, pues el más inofensivo de los animales procura grandes daños a los indios, al virreinato y en última instancia, al rey. A lo largo de la descripción de esta imagen Guaman incorpora periódicamente el suspiro que clama: «y no hay remedio». Pero si en la imagen el indio acechado simboliza a todos los indios, el autor está plenamente convencido de que las víctimas son los caciques que como él fueron sustituidos por indios bajos desatando la crisis en el Perú.

Al comparar las dos imágenes es obvio que presentan a un indio asediado, pero resulta que uno lo merece y el otro no. La misma escena sirve, primero, para simbolizar el temor como motor del orden social y de la justicia (aunque también como herramienta de la ilegitimidad de los incas del Cuzco) y, segundo, para simbolizar el temor como resultado de la injusticia cotidiana en la situación colonial.

Las imágenes, tanto naturalistas como alegóricas, cumplen la función de acompañar al texto que se refuerza con ellas. La denuncia de los abusos vía iconográfica es muy eficaz, pero precisamente por la vehemencia que logran captar las imágenes y por lo abrumadora que resulta su cantidad, es indispensable contextualizarlas en función del texto escrito, de lo contrario puede escapar al espectador si lo que el autor pretendía

57 Guaman Poma de Ayala, Nueva corónica y buen gobierno, f. 695 [709] era mostrar las ventajas de un sistema de justicia temible o la denuncia de un orden en crisis.

\section{Las virtudes del cuerpo y las virtudes del alma}

Las imágenes de los vicios y las virtudes incas pueden encontrar dificultades para ser reconocidas exclusivamente. Aunque para Guaman las virtudes del cuerpo se relacionan con las del alma, los retratos de los doce incas, las doce coyas y de los señores y señoras de los cuatro suyus, difícilmente dan cuenta del carácter de cada uno de ellos. Los siguientes casos solo intentan ejemplificar la dificultad de seguir, mediante un análisis estructuralista de la disposición de las formas, las asociaciones que Guaman hace entre diferentes vicios y virtudes respecto al cuerpo y, por ende, la indispensable necesidad de acudir a los textos. En el primer ejemplo, el retrato del Quinto Ynga (Figura 11), trasluce el juicio de Guaman, pues en la lámina correspondiente se representa a la idolatría por medio de un demonio alado que bebe al mismo

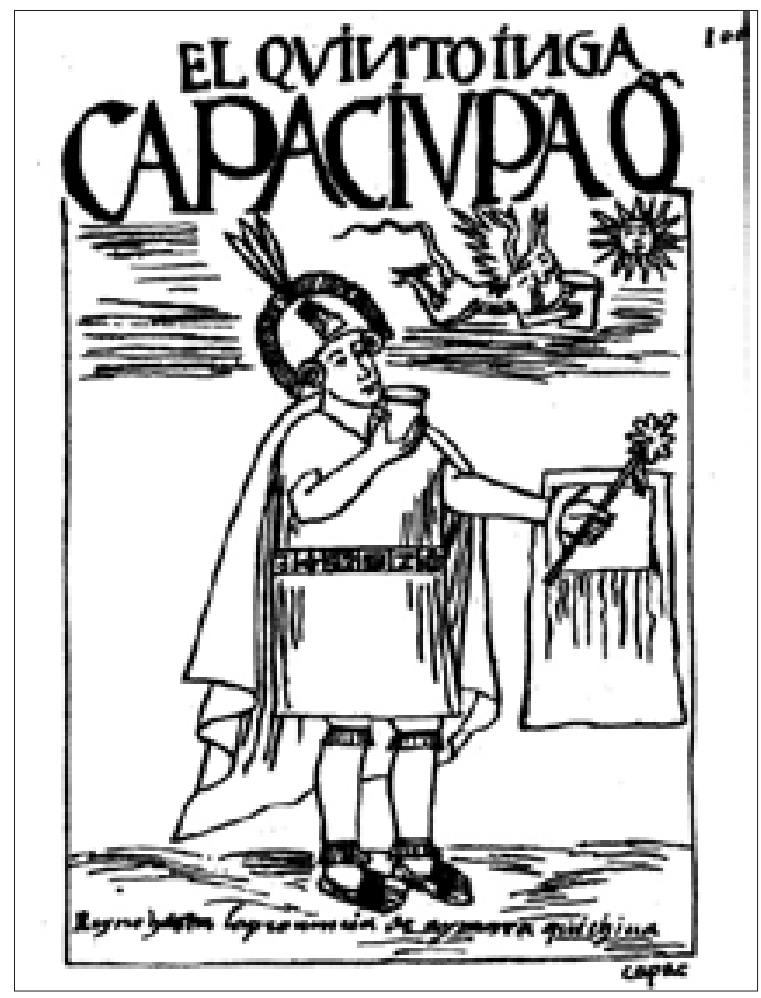

Figura 11.

El quinto Ynga, Capac Yupanqui Ynga, f. 100 [100]. 
Figura 12.

El sexto Ynga, Ynga Roca, con su hijo, f. 102 [102].

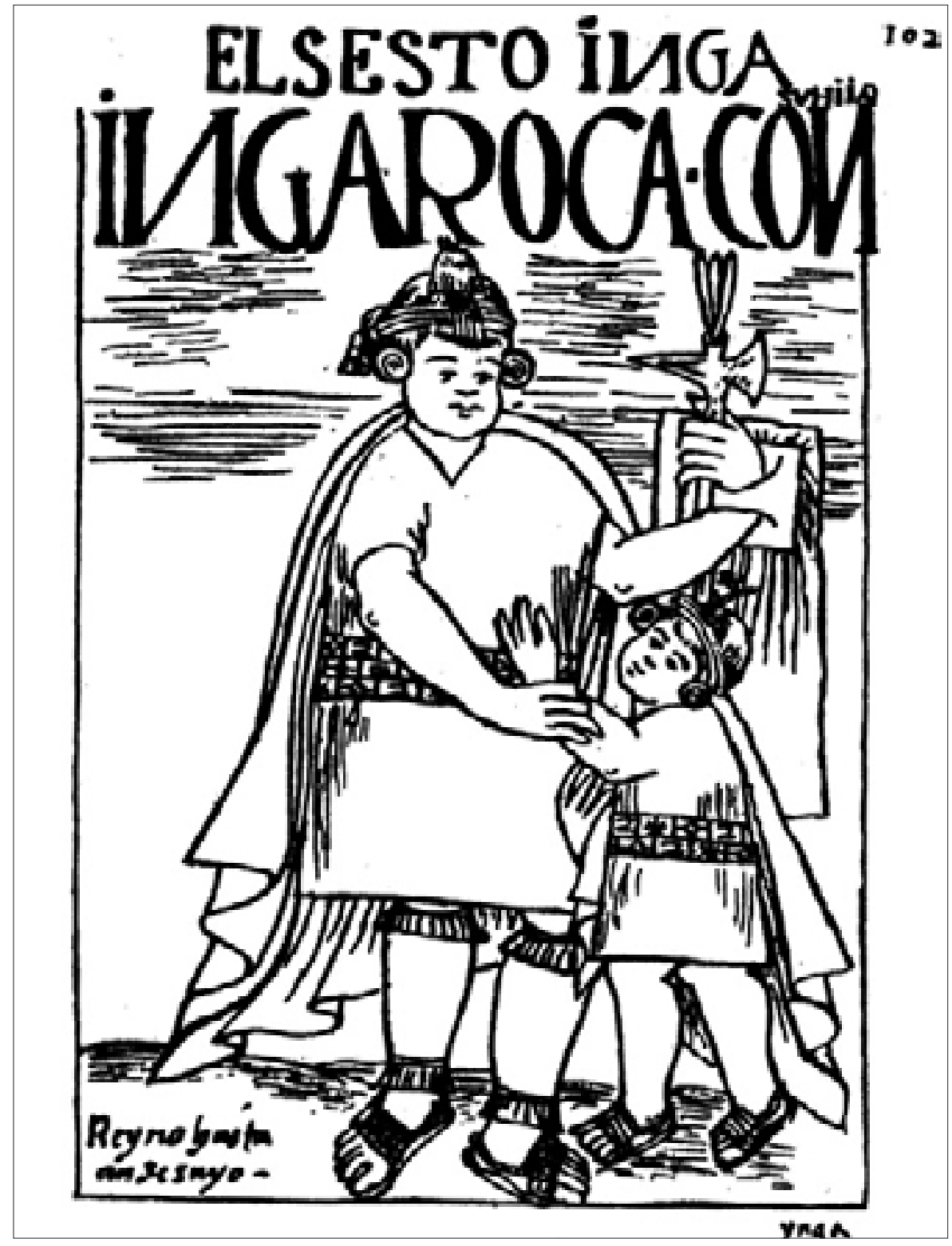

tiempo que lo hace el Inca Capac Yupanqui. ${ }^{58} \mathrm{Su}$ cuerpo, al que el autor describe como medianito, no da la clave para la evaluación moral del personaje.

En otros casos, la complexión física sí da un atisbo de su carácter: Inca Roca es dibujado con complexión notablemente gruesa, casi gordo, y con su hijo de la mano $^{59}$ (Figura 12), y en la descripción, Guaman lo llama «gran xugador y putaniero, amigo de quitar hazienda de los pobres», ${ }^{60}$ características que no se coligen del retrato, aunque pueden vincularse bajo el principio aristotélico de que las facultades morales

58 Guaman Poma de Ayala, Nueva corónica y buen gobierno, f. 100 [100]. 59 Guaman Poma de Ayala, Nueva corónica y buen gobierno, f. 102 [102]. 60 Guaman Poma de Ayala, Nueva corónica y buen gobierno, f. 103 [103] e intelectuales se reflejan en el aspecto físico, pues siempre que Guaman dibuja a algún personaje gordo, le asocia ciertos vicios; los más evidentes, aunque no exclusivos, son los vinculados a la pereza.

Lo mismo sucede con la calificación del físico que Guaman presenta de la tercera señora, Capac Ome Tallama, (Figura 13), pues la asocia a la jerarquía de la región a la que representa respecto al Cuzco. Guaman la describe: «Esta señora fue muy bizarra, hermosa; de puro gorda quedó fea que to[dos] de la casta son gordícimos y floxas, encapases, pucilánimos». ${ }^{61}$ Hasta ahí es claro cómo, en este caso, Guaman extiende los vicios de la señora a todo el pueblo del

61 Guaman Poma de Ayala, Nueva corónica y buen gobierno, f. 177 [179]. 


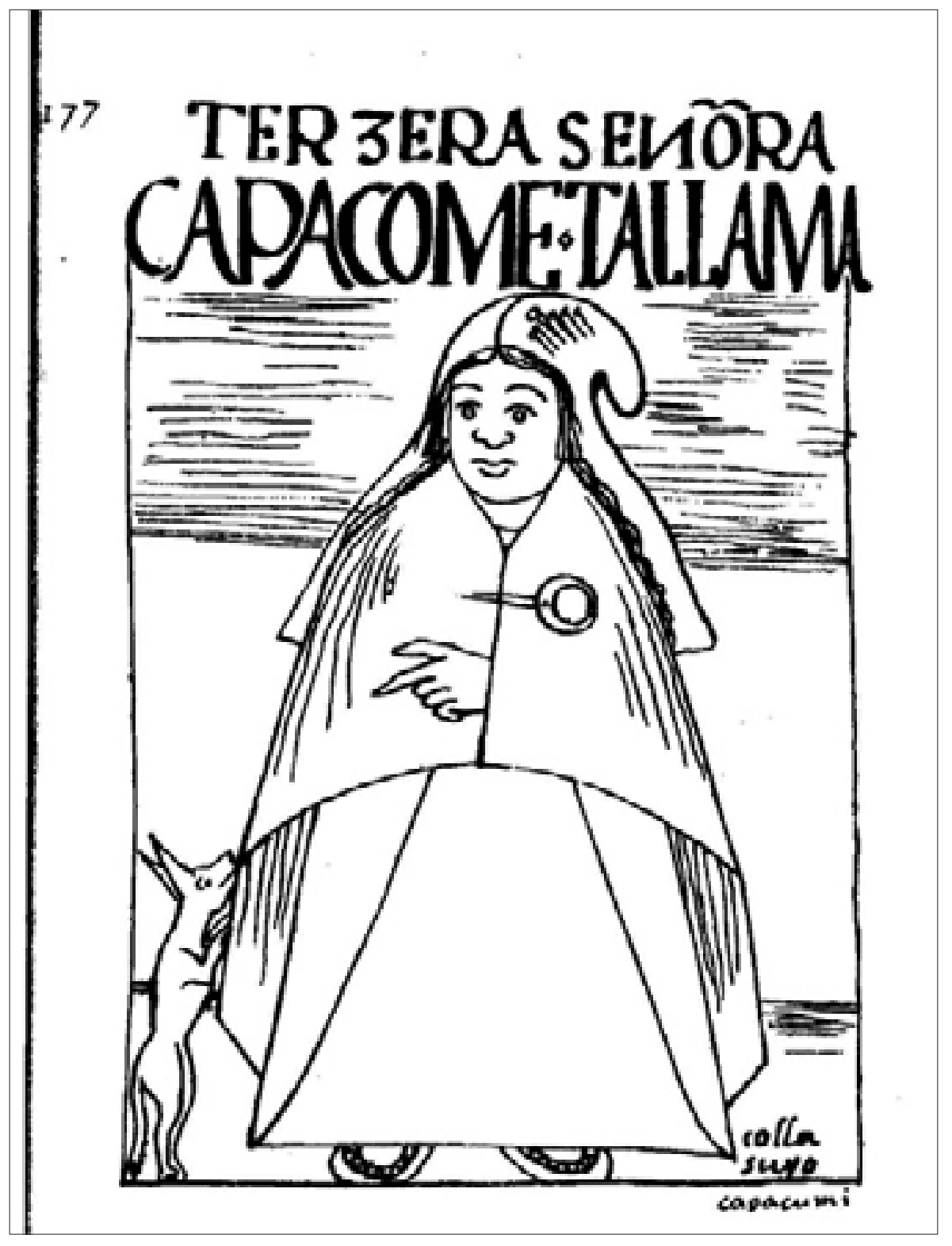

Figura 13.

La tercera señora, Umita Llama, f. 177 [179].

Colla Suyo, espacio que dentro de la jerarquización espacial andina corresponde al Hurin.

El retrato incluido, en cambio, solo presenta, en el centro de la lámina, a una mujer de complexión gruesa y, del lado derecho de ella, aparece un perro que muerde su falda. La ilustración, en efecto, da cuenta de la gordura, pero no explica relación alguna con una hermosura previa; tampoco insinúa el carácter pusilánime ni de la señora ni del pueblo ni mucho menos de la riqueza de la zona. Guaman continúa su descripción así: «floxas, encapases, pucilánimos, pero rrica gente llámase Colla capac, rrica de plata de Potocí y de oro de Carauaya, el más fino oro de todo el rreyno. Y rrica de ganados [...].
Y rrica de papa, chuno y moraya, quinua, pobre de mays y trigo y uino». ${ }^{62}$

En este particular caso resulta complicada la asociación de la hermosura con la riqueza y de la gordura con los vicios, todo en una sola persona. Pues después de llamarlos ricos vuelve a arremeter contra la gente del Collasuyu: «Y son grandotes animales. $Y$ ací todos los hombres o mugeres grandotes, gordos, sebosos, floxos, bestias sólo es para comer y dormir». ${ }^{63} \mathrm{La}$ incompatibilidad entre la flojera y la riqueza parece no contrariar el juicio y la representación que hace Guaman de esta señora y de su pueblo.

62 Guaman Poma de Ayala, Nueva corónica y buen gobierno, f. 177 [179]. 63 Guaman Poma de Ayala, Nueva corónica y buen gobierno, f. 177 [179]. 
Figura 14.

El primer Ynga, Mango Capac Ynga, f. 86 [86].

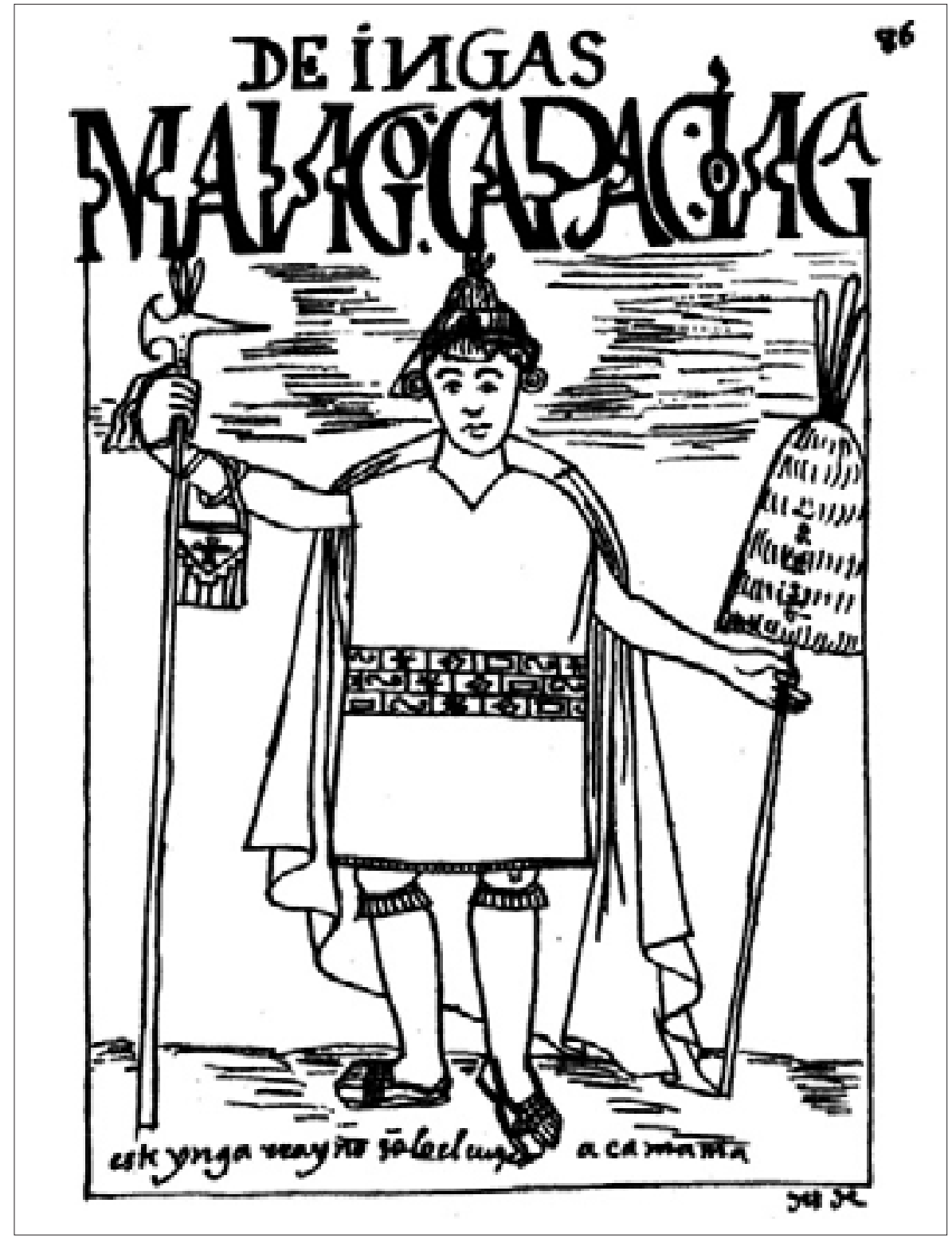

Pero dos de los ejemplos más notables de la incapacidad de las imágenes para transmitir la evaluación moral que Guaman hace de ellos, son los retratos del primer Inca Manco Capac (Figura 14) y el del décimo Topa Ynaga Yupanqui (Figura 15).

Resulta imposible inferir la opinión que Guaman Poma tenía de Manco Capac, que por cierto era muy adversa, a partir de la imagen de él que aparece en la obra. En el texto surgen diversas condenas del autor al fundador del linaje inca de Cuzco. "Que este dicho Ynga [...] no tubo pueblo ni tierra ni chacara [sementera] ni fortaleza ni casta ni parientes antigualla» ${ }^{64}$ $\mathrm{y}$ «no tubo padre conocido; por eso le digeron hijo del sol». ${ }^{65}$ Estas afirmaciones implicaban una ilegitimidad innata al primer Inca, no solo por la dudosa reputación de su mamá Mama Uaco, a la que acusa de hechicera e idólatra, sino por ser advenedizos, sin tierras ni derechos sobre ellas. Y mientras que en la imagen es indiscutible el rango del personaje por la orejeras que porta, en el texto se advierte "Que todos los que tienen orexas se llaman yngas, pero no son perfetos, cino son yndios pobres y

64 Guaman Poma de Ayala, Nueva corónica y buen gobierno, f. 80 [80]. 65 Guaman Poma de Ayala, Nueva corónica y buen gobierno, f. 81 [81]. 


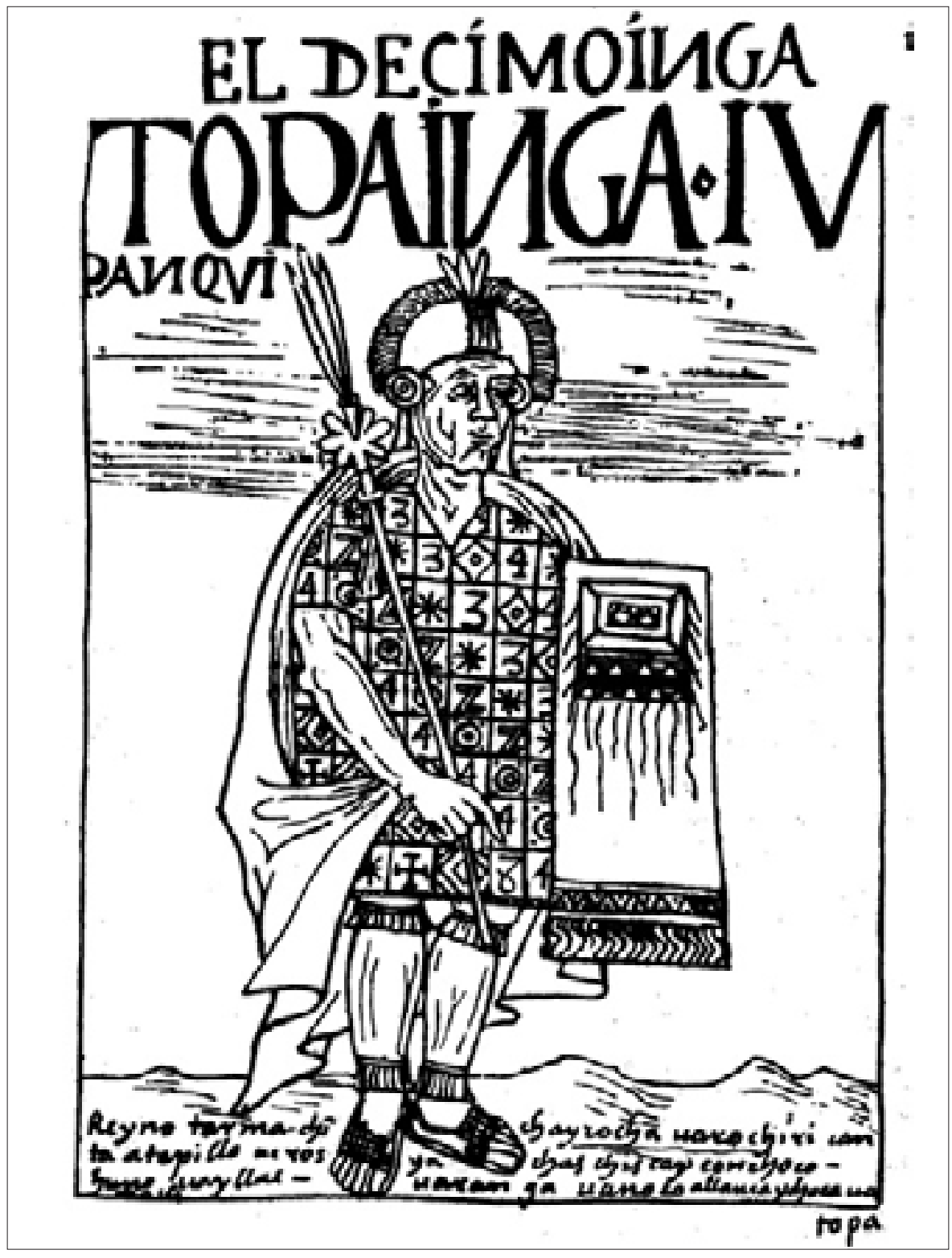

Figura 15.

El octavo Ynga, Uira Cocha Ynga, f. 106 [106].

gente uaja ni son caualleros, cino picheros». ${ }^{66}$ Con ello, Guaman hace extensivo su hostil veredicto del primer gobernante al resto de su estirpe. Pero de todos sus vicios, el más deleznable es la idolatría: «y no tubo guerra ni batalla, cino ganó con engaño y encantamiento, ydúlatras. Con suertes del demonio comensó a mochar [adorar] uacas ýdulos». ${ }^{67}$ Ninguna de estas características se presenta en la imagen del Inca, lo que nos obliga a recuperar la relación intrínseca que el autor concibió en primera instancia.
En el caso de Topa Ynga Yupanqui, el caso es inverso. Su descripción es prolija en elogios, desde la misma descripción física que hace de él hasta su carácter justiciero y valeroso.

Muy gentil hombre, alto de cuerpo y muy gran sauio y muy entonado, pas y amigo con los prencipales y caualleros y amigo de fiestas y uanquetes, amigo de honrrar a las mugeres prencipales y grandícimo hombre de guerra, enemigo de mentirosos; que por una mentira, lo mandaua matar. [...] Y honrraua a los grandes señores y hazía mucha merced y mucha limosna. Y mandaua guardar las dichas hordenansas antiguas y después por ella hizo otras hordenansas. ${ }^{68}$ 
Guaman reconoce a este Inca como diligente, tanto por sus conquistas como por haber emprendido varias obras públicas, por haber administrado la hacienda con orden y cuenta y por haber establecido la estructura burocrática con diferentes cargos políticos como el tocricoc, al que Guaman asocia con los corregidores, y tantos otros nombramientos a los que también les encuentra correspondencia con la estructura virreinal.

Pero si contrastamos la imagen con la descripción, como en el caso de Manco Capac, no es posible deducir el cúmulo de virtudes que le atribuye a este gobernante. Pero al considerar la obra como un todo y al situarla en función de las necesidades vitales del autor, es posible advertir que, tal vez, el virtuosismo de este Inca esté relacionado con el hecho de que fue contemporáneo del abuelo del autor «el capac apo Guaman Chaua», con quien establecería una relación que, a la postre, serviría a Guaman Poma para abonar a su causa y presentarse como el candidato idóneo para fungir como consejero del Rey.

El que el texto complemente las descripciones de los personajes presentados en los dibujos no es algo que se haya negado ni despreciado; sin embargo, para el caso de los vicios y las virtudes podemos decir que las imágenes en sí mismas no contienen los códigos suficientes para que estos sean descifrados de manera aislada. En cambio, el análisis de conjunto de los doce dibujos que representan a los incas, en permanente cotejo con los textos que los acompañan, puede darnos luz sobre los códigos iconográficos de Guaman. Para ello se requiere contrastar, simultáneamente, las doce imágenes con los textos que las acompañan, pero en tanto no es esa la intención de este trabajo, valgan por ahora las siguientes conjeturas: aquellos incas de carácter menos virtuoso aparecen mostrando la parte interior del escudo, mientras que aquellos que se destacan por su valerosidad empuñan el escudo de frente. Alguna otra conclusión se puede sacar a partir del número de atados que cada uno tiene en las sandalias, o del número y símbolos representados en las bandas de tocapú que ostentan en sus ropas o incluso de aquellos que aparecen simulando algún movimiento, pues las posturas que sugieren agitación suelen coincidir con la atribución de algunos vicios. Pero a pesar de que una aproximación de esta índole tendría que conceder absoluta centralidad a las imágenes, requiere también de la complementariedad, pensada por el propio autor, entre estas y los textos que las acompañan. ${ }^{69}$ De modo que solo a partir de la comparación del grupo de dibujos y mediante el permanente cotejo con lo escrito sería posible descifrar los códigos iconográficos de raigambre andina.

\section{Consideraciones}

Para Guaman Poma, la templanza y sus derivados - la piedad, la mesura, la moderación- son cualidades que pueden ser relegadas del cuadro de virtudes si con ello se garantiza la justicia. Su noción de la justicia, comenzando por la justicia divina, está estrechamente relacionada con el temor, pues en su concepción el que teme a Dios y a la justicia observa los mandamientos y las normas. Por ello, el modelo de justicia incaico le parece el más eficiente; sanciona las infracciones de forma ejemplar, sus castigos son tan brutales que disuaden al posible infractor e incluso obstruyen todo intento de rebelión. Los incas eran temidos y por ello había orden y acatamiento de las leyes, en cambio los corregidores, encomenderos, padres de doctrina y demás vulneraban el orden por no temer ni a Dios ni a la justicia. Bajo esta perspectiva, sus imágenes de los castigos incas son tan impactantes por la violencia mostrada como aquellas en las que denuncia el abuso.

Por otro lado, la soberbia aparece en las imágenes como el fundamento de los abusos, no solo en términos alegóricos sino escrita en la base de los dibujos que representan abusos. En este sentido, el contraste entre vicio y virtud es claro cuando se trata de personajes españoles y no lo es tanto

69 La dependencia de las imágenes hacia el texto se advierte desde el momento mismo en que el código de color de los vestidos está cifrado en este último, pues los dibujos a tinta impidieron incluirlo en ellos; sin embargo, para el autor era de suma relevancia incorporar esa información, de modo que la escribe en cada uno de los casos. 
en las imágenes de los indios, pues en principio asume que hay indios virtuosos, como él mismo y su linaje, y otros viciosos y corrompidos como los incas o los indios bajos, de modo que tanto las imágenes como las descripciones de los indios muestran mayor ambigüedad en lo que a su carácter se refiere, pues, en cada caso, el autor decide hacer matices, aclaraciones y vinculaciones particulares de acuerdo con los intereses que lo mueven a buscar, por medio de su obra, un lugar dentro del nuevo orden colonial.

Es así que el vasto y sobrecogedor repertorio de imágenes en las que aparecen indios violentados, encuentra su sentido más extenso dentro de una explicación historiográfica que contempla el marco de referencias en el que la obra alcanza su mayor significación. Pero si, en términos historiográficos, la separación entre las imágenes y el texto no encuentra sustento y es más bien ajena a la intención del autor, la recurrencia de hacerlo, sin duda, se debe a razones de peso. El amplio margen de interpretación que permiten las imágenes por sí solas estimula la proliferación de propuestas; algunas de ellas buscan afianzar un ideal de la cultura andina que permita sustentar una identidad indígena y que sirva de fundamento a las iniciativas de reescritura de la historia de los pueblos andinos, los cuales han resignificado la obra desde su propia óptica en aras de la movilización política. Por ende, las imágenes tendrán siempre un amplio horizonte hermenéutico. Sin embargo, ni la pragmática política ni el análisis estructuralista están exentos de considerar el vínculo esencial que el autor le confirió a su discurso, al no escindir en él tradiciones nítidas, indígenas o europeas, y al concebir texto e imágenes como un todo.

\section{Bibliografía}

Adorno, Rolena. «Paradigmas perdidos: Guaman Poma examina la sociedad española colonial». Revista Chungará, n. 13 (1984): 67-91.

Adorno, Rolena. «Sobre el lenguaje pictórico y la tipología cultural en una crónica andina». Revista Chungará, n. ${ }^{\circ} 18$ (1987): 101-143.
Beristáin, Helena. Diccionario de retórica y poética. México: Porrúa, 1997.

Borja Gómez, Jaime. «Idolatría, tiranía y barbarie. La construcción del indígena en una crónica indiana». En Passeurs, mediadores culturales y agentes de la primera globalización en el Mundo Ibérico, siglos XVI-XIX, editado por Scarlett O’Phelan y Carmen Salazar-Soler, 33-57. Lima: Editorial Pontificia Universidad Católica del Perú, 2005.

Bouzy, Christian. «El emblema: un nuevo lugar estético para los antiguos lugares éticos». Criticón, n. 158 (1993): 35-45.

Fossa, Lydia. Narrativas problemáticas. Los inkas bajo la pluma española. Lima: Pontificia Universidad Católica del Perú, Instituto de Estudios Peruanos, 2006.

GKS 2232 40: Guaman Poma, Nueva corónica y buen gobierno (1615). Biblioteca Real de Dinamarca. http://www.kb.dk/permalink/2006

González, Carlos, Hugo Rosati y Francisco Sánchez. Guaman Poma. Testigo del mundo andino. Santiago: LOM Ediciones - Centro de Investigaciones Barrios Arana, 2003.

González, Carlos, Hugo Rosati y Francisco Sánchez. «Sinopsis del estudio de la iconografía de la Nueva corónica y buen gobierno escrita por Felipe Guaman Poma de Ayala». Historia (Santiago) 34, (2001): 67-89.

Guaman Poma de Ayala, Felipe. El primer nueva corónica y buen gobierno (Edición crítica revisada para la versión digital de John V. Murra y Rolena Adorno. Traducciones y análisis textual del quechua por Jorge L. Urioste). Copenhague: Biblioteca Real de Dinamarca, 2001. http://www.kb.dk/permalink/2006/poma/ info/es/frontpage.htm

Holland, Augusta E. Nueva corónica: Tradiciones artísticas europeas en el virreinato del Perú. 
Cuzco: Centro de Estudios Regionales Andinos Bartolomé de las Casas, 2008, 36- 40.

López-Baralt, Mercedes. Ícono y conquista: Guaman Poma de Ayala. Madrid: Hiperion, 1988.

Lozada Pereira, Blithz. Cosmovisión, historia y politica en los Andes. La Paz: CIMA, 2006.

O'Gorman, Edmundo. Cuatro historiadores de Indias, Siglo XVI. México: Alianza Editorial Mexicana - Consejo Nacional para la Cultura y las Artes, 1972.

O'Gorman, Edmundo. «Historia y vida». En $L a$ teoria de la bistoria en México (1940-1973), editado por Álvaro Matute, 121-151. México: SEP, 1974.

Ossio, Juan M. En busca del orden perdido. La idea de la Historia en Felipe Guaman Poma de Ayala. Lima: Pontificia Universidad Católica del Perú, 2008.

Pérez Gerardo, Diana Roselly. «Historiografía de tradición indígena en el Perú». Tesis de Doctorado en Historia, UNAM, 2017.

Porras Barrenechea, Raúl. El cronista Felipe Huaman Poma de Ayala. Lima: Ediciones Bendezú, 1971.

Real Academia Española, Diccionario de autoridades. Madrid: Gredos, 2002. [Facsímil de: Diccionario de la lengua castellana. Madrid: Francisco del Hierro, 1726].
Rivadeneira, Pedro de. «Tratado de la religión y virtudes que debe tener el príncipe cristiano para gobernar y conservar sus estados, contra lo que Nicolás Maquiavelo y los políticos de este tiempo enseñan». En Obras escogidas con una noticia de su vida y juicio critico de sus obras de Vicente de la Fuente. Madrid: Atlas, 1952.

Rivera Cusicanqui, Silvia. «Sociología de la imagen. Una visión desde la historia colonial andina». En Ch'bixinakax utxiwa. Una reflexión sobre prácticas y discursos descolonizadores, 1952. La Paz: Tinta Limón - Retazos, 2010.

- Recibido: 24 de febrero de 2017

Aprobado: 13 de octubre de 2017

- Disponible en línea: 31 de diciembre de 2017

\section{Cómo citar este artículo}

Pérez Gerardo, Diana Roselly. «Los vicios y virtudes en las imágenes de la Nueva corónica y buen gobierno de Felipe Guaman Poma de Ayala: la violencia entre la justicia y la soberbia». Memoria y Sociedad 21, n. 43 (2017): 104-130. https://doi. org/10.11144/Javeriana.mys21-43.vvin 